\title{
Kavram ve Anlam Boyutu Perspektifinde Arapçada Siyah Renk
}

\author{
Rifat Akbaş \\ Dr. Öğr. Üyesi, Van Yüzüncü Yıl Üniversitesi, İlahiyat Fakültesi, \\ Arap Dili ve Belagati Ana Bilim Dalı \\ Van/Türkiye \\ akbasakbasa.1988@hotmail.com \\ http://orcid.org/0000-0002-8533-3335
}

Özet: Sözcük dağarcığı, zengin içerikli düşünce kalıpları, erillik-dişillik olgusu, az sözcükle geniş anlatı olanaklarını sağlaması, ikincil ve yan anlamları ihtiva etme potansiyeli, türeme kapasitesinin genişliği ve ince anlam ayırımları gibi nitelikler Arap dilinin zenginliğini belirleyen özellikler arasında öne çıkanlardır. Siyah rengin kavram ve anlam boyutu etrafında şekillenen söz varlığı Arap dilinin bu özelliklerini yansıtan spesifik örneklerden sadece bir tanesidir. Bu bağlamda makalede siyah renk nitel araştırma yöntemine bağlı kalınarak gerek adlandırılma ve belirgin kılınma gerekse bazı duygu ve düşüncelerin aktarım aracı yapılması noktasında muteber sözlükler ve klasik Arap şiiri referans alınarak incelenmiştir. Siyah rengin sözlük anlamını karşılayan kavramlar dışında açıklanmaya çalışıldığı, farklı bakış açılarıyla tanımlanması, beyaz renk ile olan kombinasyonu, özellikle de ilgili olduğu varlığın temel alınmasıyla hem olumsuz çağrışımların hem de bireysel arzu ve özlemlerin mecazi dili yapıldığı gibi hususlar makalenin ana temasını teşkil etmektedir. Makalede siyah renk ile yapılan birtakım farklı adlandırma ve ifade tarzlarının Arap kültürüyle olan bağlantısına da dikkat çekilmiştir. Anahtar Kelimeler: Arap Dili, Arap Edebiyatı, Siyah, Kara, Renk.

Araştırma Makalesi/Research Article

Atıf/Citation: Akbaş, Rıfat. "Kavram ve Anlam Boyutu Perspektifinde Arapçada Siyah Renk". Uludă̆ Üniversitesi İlahiyat Fakültesi Dergisi 30/2 (Aralık 2021), 571-598. https://doi.org/10.51447/uluifd.995537 


\title{
The Black Colour in Arabic in Perspective of Concept and Meaning Dimension
}

\begin{abstract}
Such qualities as vocabulary source, thinking patterns with rich content, masculinity-femininity phenomenon, providing opportunities for expressing large narrations with few words, the potential of containing the secondary and side meaning, the ability for literary arts, the breadth of the derivation capacity and subtle distinctions of meaning are the qualities which stand out the properties determining the richness of Arabic Language. The existence of words formed around the concept and meaning dimension of the colour black is solely one of the specific examples reflecting these properties in Arabic language. Within this context, in this article, the black colour was studied in detail by referencing reliable dictionaries and classical Arab poetry in terms of making it a tool for both naming and determining and also transferring senses and thought. The issues such as the colour black tried to be explained excluding concepts meeting its lexicon meaning, and defined in different perspectives, and its combination with white colour, and metaphorically both negative connotations and individual desire and longings made specifically, make the main theme of the article by taking the being in question. The connection between some different naming and expression styles and Arabic culture made with black colour in this article were also called attention to.
\end{abstract}

Keywords: Arabic Language, Arab Literature, Concept, Meaning, Black, Colour. [You may find an extended abstract of this article after the bibliography.]

\section{Giriş}

Duygu ve düșünceler bazen fiili olarak ortaya konulurken çoğu zaman dil aracıl1ğıla muhataba yansıtılmaktadır. Gerek fiilen gerekse dil aracılığıyla aktarılan duygu ve düşüncelerin tamamının dış dünya ile olan bağlantısı ise tabiî bir durumdur. Başka bir ifadeyle kişiyi olumlu veya olumsuz şeyler yapmaya veya söylemeye sevk eden faktörlerin tümü onun doğrudan gördüğü ve hissettiğiyle alakalıdır. Kuşkusuz bu da, toplumun hayat tarzında ve sözlü kültürünün oluşmasında sosyal çevrenin oldukça etkin bir role sahip olduğunu göstermektedir.

Sosyal çevrenin bir parçası olarak renkler de kişinin duygusal söylemlerini önemli ölçüde etkileyen faktörler arasında yer alır. Aslında renk algısı hayatın akışı içerisinde coğrafyadan coğrafyaya, kültürden kültüre farklılık arz ediyorsa da siyah renk etrafında gelişen sözlü edebiyatta olumsuzluk çağrışımları daha ağır basmaktadır. Konu Arap edebiyatı olunca özgürlügün yanı sıra güzellik ve çekiciliğin sembolü sayılan beyaz rengin karşıtı siyah renge, sadece sevgilinin saçı, gözleri ve vücudundaki benler söz konusu olduğunda olumlu bakılmıştır. Bu renk, ötekileştirme söylemleri, aşağılama ve hakir görme eylemleri, yıkım ve tahribatın emareleri, acı, keder ve ürperticiliğin sembolize edilmesi gibi durumlarda daha fazla kullanılmıştır. Kısacası bazen güzel sözlerin muharriki olan siyah renk çoğu zaman kötülük ve menfi tutumların tasvirinde kullanılmıştır. Bu denli yaygın kullanılmasından olsa gerektir ki kimi âlimlere göre beyaz, kırmızı, sarı ve yeşil ile birlikte yüce Allah tarafından yaratılan 
beş ana renkten sayılmış, ${ }^{1}$ kimilerine göre sadece beyaz renk ile birlikte tüm ara renklerin temeli kabul edilmiştir. ${ }^{2}$

Öte yandan Arap dilinde siyah renge yüklenilen anlamlar kadar bu rengin ifade edilmesinde kullanılan sözcükler ve siyahlığın pekiştirilmesi noktasında başvurulan kalıp ifadeler oldukça fazladır. Bu da söz konusu rengin kavram ve anlam boyutunun bilinmesini önemli kılmaktadır. Bu bağlamda makalede siyah renk muteber sözlüklerde yer alan açıklamalar ve klasik Arap şiirinden seçilen beyitler doğrultusunda incelenmeye çalışılmıştır. Zira herhangi bir kavramın analizi yapılırken birer primitif sözlük çalışması kabul edilen klasik dönem şairlerinin divanları ve antoloji mahiyetindeki şiir mecmualarının incelenmesi ${ }^{3}$ kavramsal değişimin izlerinin takibi açısindan önem arz etmektedir.

Serpil Bağcı'nın 1996 yılında kaleme aldı̆̆ı “İslam Toplumlarında Matemi Simgeleyen Renkler: Mavi, Mor ve Siyah" adlı makalesi ${ }^{4}$ gibi Emel Mahmûd Abdülkādir Ebû Avn'ın 2003'te hazırladığı el-Levn ve eb âduh fi'ş-şi'ri'l-Câhilî başlıklı tezinde bahse konu olan renk ile birlikte beyaz, kırmızı, yeşil, sarı ve mavi renkler sadece muallakat şairlerinin şiirleri doğrultusunda irdelenmiştir. ${ }^{5}$ Nesrin Bayraktar Erten'in 2004 yılında yayımlanan "Kara ve Siyah Renk Adlarının Türkçedeki Kavram ve Anlam Boyutu Üzerine”, 6 Behiye Asude Özcan tarafından 2018 yılında yazılmış olan "Türk ve Slav Kültüründe Siyah Renk"7 ve Hüseyin Güfta'ya ait olan "Bâkî Divanı'nda Siyah Renkli Unsurlar"8 adl makalelerde siyah renk sadece ilgili dil ve kültürler perspektifinde incelenmiştir. 2020 yılında Sevda Demir Parlak tarafindan Sanatta Yeterlilik Tezi olarak hazırlanan Kadın Giyim Modasında Siyah Renk isimli çalışma ${ }^{9}$ da siyah rengin kadın

1 Ebû Abdillâh el-Hüseyn b. Ali en-Nemerî, Kitâbü'l-Mülemmac, thk. Vecihe Ahmed es-Sezal (Dımaşk: Matbaatu Zeyd b. Sâbit, 1396/1976), 1.

2 Ebü'l-Hasen Alî b. Abdirrahmân b. Hüzeyl el-Endelüsî, Hilyetü'l-fürsân ve şu'arâu'ş-şec'ân, nşr. Muhammed Abdülganî Hasan (Kahire: Dâru'l-Maârif, 1369/1949), 83; Sa'düddîn Mes'ĉ̂d b. Fahrüddîn etTeftâzânî, Şerḥu'l-Makāṣıld, thk. Abdurrahman Umeyre (Beyrut: Âlemü'l-Kütüb, 1419/1998), 2/259; Şihâbüddîn Ahmed b. Muhammed b. Ömer el-Hafâcî, Şerhu Dürreti'l-ġavvâṣ fi evhâmi'l-havâs, thk. Meysûn Abdüsselam Necib (Abu Dabi: Dâru'l-Kütübi'l-Vataniyye, 1433/2012), 159.

3 Soner Gündüzöz, “Arap Sözlük Bilimi ve Sözlük Çalışmaları”, İslam Medeniyetinde Dil İlimleri Tarih ve Problemler, ed. İsmail Güler (İstanbul: İSAM Yayınları, 2015), 27.

4 Serpil Bağcl, "İslam Toplumlarında Matemi Simgeleyen Renkler: Mavi, Mor ve Siyah”, Ankara Türk Tarih Kurumu Yayınları, 2 (1996), 163-168.

5 Emel Mahmûd Abdülkādir Ebû Avn, el-Levn ve eb'âduh fi'ş-şi'ri'l-Câhilî Şu'arâ’ü'l-mu'allakāt enmûzecen (Nablus: Câmi ‘âtü'n-Necâh el-Vataniyye, Yüksek Lisans Tezi, 2003), 51-107.

6 Nesrin Bayraktar Erten, "Kara ve Siyah Renk Adlarının Türkçedeki Kavram ve Anlam Boyutu Üzerine”, Dil Dergisi, 126 (2004), 56-77.

7 Behiye Asude Özcan, "Türk ve Slav Kültüründe Siyah Renk”, Akademik Tarih ve Düşünce Dergisi 5/18 (2018), 269-292.

8 Hüseyin Güfta, "Bâkî Divanı'nda Siyah Renkli Unsurlar”, Turkish Studies, International Periodical For the Languages, Literature and History of Turkish or Turkic, 4/8 (2009), 1314-1373.

9 Sevda Demir Parlak, Kadın Giyim Modasında Siyah Renk (İzmir: Dokuz Eylül Üniversitesi Güzel Sanatlar 
giyim modasındaki konumu ve tercih edilme nedenleri üzerine durulmuştur.

Bu makalede ise Arap dili özelinde ve klasik döneme bağlı kalınarak sadece siyah rengin kavram ve anlam boyutu ele alınmıştır. Makale bu yönüyle yukarıda sözü edilen çalışmalardan farklılık arz etmektedir. Ülkemizde özellikle belli bir rengi Arap dili ve edebiyatı ekseninde irdeleyen akademik araştırmaların gerekliliğ̈ine binaen makalenin kayda değer bir boşluğu dolduracağı ümit edilmektedir.

\section{Siyah Rengin Kavram Boyutu}

Bu başlıkla, bir anlamın farklı sözcüklerle dile getirilmesine ek olarak bu anlamı karşılayan sözcüklerin yapıları, tanımları ve türevleri hakkındaki bilgi aktarımı kastedilmektedir. Binaenaleyh ilgili ana başlığın alt başlıkları altında siyah renk anlamına gelen bazı sözcüklerin etimolojik tahlilleriyle birlikte gerek edebiyatçılar gerekse toplum tarafından öne sürülen kullanımlarına dikkat çekilecektir.

\subsection{Siyah Renk Anlamında Kullanılan Sözcükler}

Genel anlamda siyah renk için kullanılan sözcüklerin kökü s - و - warflerinden oluşmaktadır. Bu yüzden gerek sözlüklerde gerekse edebî yapitlarda en fazla أَسْوَ ve سَو sözcükleri karşımıza çıkmaktadır. أَ أموَّ sözcüğü, canl1-cansız fark etmeksizin siyah, simsiyah ve koyu renkler ile kademeli olarak gerçekleşen kararma için kullanılmak-

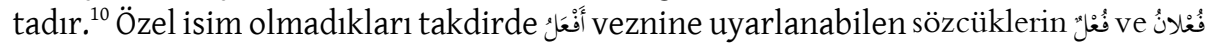
vezinleri doğrultusunda kırık çoğul yapılması gerektiği dikkate alındığında bu sözcüğün سُو ve vُودان şeklinde iki tane çoğulunun olduğunu söylemek mümkündür. ${ }^{11}$ Öte

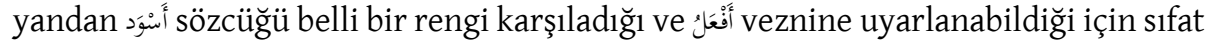
müşebbehe kategorisinde değerlendirilmektedir. ${ }^{12} \mathrm{Bu}$ kategorinin vezinleri duyuma ( $)$ bağlı olsa da renkler için söz konusu vezin kıyasî addedilmiştir. ${ }^{13}$

Enstitüsü, Yüksek Lisans Tezi, 2020).

10 Ebû Yûsuf Ya'kūb b. İshâk İbnü's-Sikkît, Kitâbü'l-Elfâz, thk. Fahreddîn Kabâve (Beyrut: Mektebetu Lübnan, 1998), 153; Ebü'l-Fazl Cemâlüddîn Muhammed b. Mükerrem İbn Manzûr, Lisânü'l-‘Arab. thk. Komisyon (Beyrut: Dâru Sâdır, ts.), "sevede”, 3/224; Ebü'l-Abbâs Ahmed b. Muhammed b. Alî el-Feyyûmî, el-Miṣbâhu'l-münîr fì garîbi'ş-şerḥi'l-kebîr li'r-Râfi'î, thk. Abdülazîm eş-Şinnâvî (Kahire: Dâru'l-Maârif, 1397/1977), "sevâd”, 294; Mecdüddîn Muhammed b. Yackūb b. Muhammed el-Fîrûzâbâdî, el-Ḳāmûsü'lmuhît, thk. Komisyon (Beyrut: Müessesetü’r-Risâle, 1426/2005), “sûd”, 290. Ebü'l-Feyz Muhammed elMurtazâ b. Muhammed el-Hüseynî ez-Zebîdî, Tâcü'l-'arûs min cevâhiri'l-Kāmûs, thk. Hüseyin Nessâr (Kuveyt: Matbaatu Hukûmeti'l-Kuveyt, 1969), "humr”, 8/226, 227.

11 Ebû Bişr Sîbeveyhi Amr b. Osmân b. Kanber, el-Kitâb, thk. Abdüsselâm Muhammed Hârûn (Kahire: Mektebetü'l-Hâncî, 1408/1988), 3/644; Ebû Bekr Muhammed b. el-Hasen b. Abdillâh ez-Zübeydî, Lahnü'l-'avâm, thk. Ramazan Abdüttevvâb (Kahire: Mektebetü'l-Hâncî, 1420/2000), 290.

12 Radiyyüddîn Muhammed b. el-Hasen el-Esterâbâdî, Şerḥu'r-Raḍ̂ 'ale'l-Kâfiye, nşr. Yûsuf Hasan Ömer (Bingazi: Menşûrâtu Câmiati Karyûnus, 1996), 3/432.

13 Radî el-Esterâbâdî, Şerhu'r-Radî 'ale'l-Kâfiye, 3/432. 
Bazı sözlüklerde beyaz olmayan her şeyin rengini ifade etmede kullanıldığı belirtilen سَوَاد sözcüğü de ${ }^{14}$ asıl anlamda sadece beyaz rengin zıddını nitelemektedir. ${ }^{15}$ Uzaklarda görünen karartı veya şahıs manasında kullanıldığında çoğulu أَسَاود ve şeklinde gelir. ${ }^{16}$ فُعَْ vezni genellikle renkleri ifade eden sözcüklerin masdar kalıbı iken bu vezne uyarlanamayan سَواد sözcügünün akşam anlamındaki مَساء sözcügüüne hamledildiği ileri sürülerek cevap verilmeye çalışılmıştır. ${ }^{17}$ "Cemaat”, “orman”, "hurma ağaçlarının bulunduğu arazi" ve "çok miktarda mal" gibi anlamlara gelen bu sözcük ${ }^{18}$ Hz. Ömer (r.a.) tarafından fethedilen aşağı Irak bölgesi ve Kûfe etrafındaki tüm taşrayı kapsayan toprakların özel ismi olarak da kullanılmaktadır. ${ }^{19}$

Siyah renk klasik Arap şiirinde سَوْاد vözcükleri ile bu sözcüklerin türevlerin dışında nadiren de olsa siyahîler için kullanılan sözcüklerle de ifade edilmiştir. Örneğin Câhiliye devri meşhur şairlerinden İmruülkays b. Hucr'a (öl. 540) ait olan ويَاُُْْْنَ

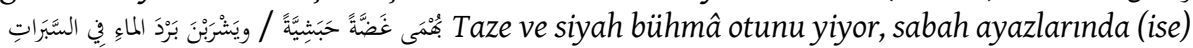
soğuk suyu içiyorlar. [Bahr-1 tavîl] $]^{20}$ beytinde merkeplerin yediği taze otun siyaha çalan yeşilliği حَِّبَzüzügüule ifade edilmiştir. ${ }^{21}$ Emevî dönemi Hıristiyan şairlerden Gıyâs b. Gavs el-Ahtal'ın (öl. 92/710-11) maşukun konakladığı çadırın yok olmaya yüz

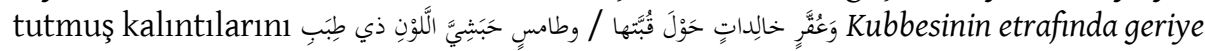

14 Ebü'l-Hüseyn Ahmed b. Fâris İbn Fâris, Mu'cemü mekāyîisi'l-luġa, thk. Abdüsselâm Muhammed Hârûn (Kahire: Dâru'l-Fikr, 1372/1972), "sevede”, 3/114; Ebü'l-Feth Burhânüddîn Nâsır b. Abdisseyyid el-Mutarrizî, el-Muǵrib fî tertîbi'l-Mu'rib, thk. Mahmûd Fâhûrî - Abdülhamîd Muhtâr (Haleb: Mektebetu Üsâme b. Zeyd, 1399/1979), "sûd", 1/419.

15 Ebû Bekr Muhammed b. el-Hasen İbn Düreyd el-Ezdî, Cemheretü’l-lüga, thk. Remzî Münîr Ba'lbekî (Beyrut: Dâru'l-i̇lm li'l-Melâyîn, 1987), “deseve”, 2/649.

16 Ebû Mansûr Muhammed b. Ahmed el-Ezherî, Tehzî̉ü'l-lugga, thk. Abdüsselâm Muhammed Hârûn vd. (Misır: ed-Dâru'l-Misriyye li't-Te’liff ve't-Terceme, ts.), "sâde", 13/31. Ebû Nasr İsmâîl b. Hammâd elCevherî, eș-Ṣıhâh tâcü'l-lüga ve Șıhâhüül-‘Arabiyye, thk. Ahmed Abdülgafûr Attâr (Beyrut: Dâru'l-i̇lm li'lMelâyîn, 1399/1979), “sevede”, 2/492.

17 Necmü'l-eimme Radıyyüddîn Muhammed b. el-Hasen el-Esterâbâdî, Şerḥu'ş-Şâfiye, thk. Muhammed Muhyiddin Abdülhamîd vd. (Beyrut: Dâru'l-Kütübi'l-İlmiyye, 1402/1982), 1/161.

18 Halil b. Ahmed, Ebû Abdirrahmân, Kitâbü'l-'Ayn müratteben alâ hurûfi'l-mu'cem, thk. Abdulhamîd Hindâvî (Beyrut: Dâru'l-Kütübi'l-İlmiyye, 1424/2003), “sevede”, 2/292; Ezherî, Tehzî́bü'l-luġa, "sâde”, 13/31; Cevherî, eș-Ṣlhâh, "sevede”, 2/726; İbn Manzûr, Lisânü'l-'Arab, "sevede”, 3/225; Fîrûzâbâdî, elKāmûsü'l-muhîț "sûd”, 290; Zebîdî, Tâcü'l-‘arûs, “sevede”, 8/235.

19 Ezherî, Tehzîibül-lugia, "sâde”, 13/33; Ebû Abdillâh Şihâbüddîn Yâkūt b. Abdillâh el-Hamevî, Mu'cemü’lbüldân, thk. Ferîd Abdülazîz el-Cündî (Beyrut: Dâru'l-Kütübi'l-İlmiyye, 1410/1990), 1/274.

20 Ebû Vehb Hunduc b. Hucr b. el-Hâris İmruülkays, Dîvânu İmri’i'l-Kays ve mulhakâtuh bi şerhi Ebî Saîd esSükkerî, thk. Enver Alyan Ebû Süveylim - Muhammed eş-Şevâbike (Birleşik Arap Emirlikleri: Merkezu Zâyid li’t-Türâs ve’t-Târîh, 1421/2000), 2/586, 587; Zübeydî, Lahnü̈l-‘avâm, 179.

21 Bühmâ otunun حبشي sözcüğüyle nitelendirildiğine ilişkin bk. Ebü’l-Hasen Alî b. İsmâîl İbn Sîde, elMuhașșaș (Beyrut: Dâru'l-Kütübi'l-i̇lmiyye, ts.), 10/163; İbn Manzûr, Lisânü'l-‘Arab, “kara'a”, 8/269; Zebîdî, Tâcü'l-‘arûs, "kara`a”, 21/543. 
kalan birçok sütunlar, kara ve pek çok silik çizgiler. [Bahr-1 basît] $]^{22}$ şeklinde nitelemesinde de aynı sözcük uzun bir zaman dilimine yenik düşen bir mekânın artık birer karartı şeklinde görünen kalıntılarının renk tasvirinde kullanılmıştır. Klasik dönem şairleri tarafından koyu renkli yağmur bulutlarının tasvirinde kullanılan سُود sözcükleri de bu örneklere dâhil edilebilir. ${ }^{23}$

Ayrıca klasik Arap şiirinde ten rengi ile zifiri karanlığın yeşil anlamına gelen أَحْضَ ve š̈zcükleriyle betimlenmeye çalışılması bu sözcüklerden siyahlık ve karanlığın kast edildiğini göstermektedir. ${ }^{24}$ Siyah rengin olumsuz, yeşilliğin de olumlu çağrışımları düşünüldüğünde Arap toplumunda özellikle ten rengine أخضر denilmesi dolaylı olarak koyu deri renginin أسو şeklinde nitelendirilmesinden duyulan rahatsızlığ 1 da akla getirmektedir. ${ }^{25}$

\subsection{Siyah Rengi Farklı Bakış Açılarıyla Açıklamaya Çalışanlar}

Ebû Osmân Amr b. Bahr el-Câhiz (öl. 255/869) siyah rengi diğer renklerle muka-

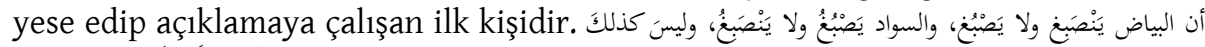

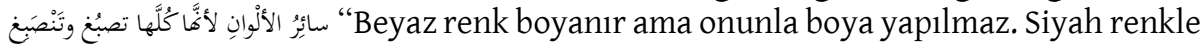
boya yapılır ancak kendisi boyanamaz. Diğer tüm renkler ise böyle değildir. Zira siyah ve beyaz dışındaki tüm renklerle hem boya yapılır hem de bu renkler boyanabilir." ${ }^{26}$ şeklinde bir açılama yapan Câhiz 'beyaz boyanır' cümlesinden görünürlüğü başka renklerle kapatılabilir; 'onunla boya yapılmaz' cümlesinden ise başka renklerin

22 Ebû Saîd el-Hasen b. el-Hüseyn b. Ubeydillâh es-Sükkerî, Şi'ru'l-Ahțal Ebî Mâlik Gilyâs b. Ġavs et-Tag̉lebî, thk. Fahreddin Kabâve (Dımaşk: Dâru'l-Fikr, 1414/1996), 174.

23 Ebû Züeyb Huveylid b. Hâlid b. Muharris el-Hüzelî, Dîvânu Ebî Zü̉'eyb el-Hüželī, thk. Ahmed Halīl eş-Şāl, (Port Said: Merkezu'd-Dirâsât ve'l-Buhûsi'l-İslâmiyye, 1435/2014), 82; Ebû Saîd el-Hasen b. el-Hüseyn b. Ubeydillâh es-Sükkerî, Dîvânu'l-Hüzeliyyîn (Kahire: Matbaatu Dâri'l-Kütübi'l-Mısriyye, 1995), 1/51, 52.

24 Ebû Nevfel Bişr b. Ebî Hâzim el-Esedî, Dîvânu Bişr b. EbîHâzim el-Esedî, nşr. Mecîd Tarrâd (Beyrut: Dâru'lKitâbi'l-Arabî, 1415/1994), 78; Ebû Sa'de eş-Şemmâh b. Dirâr b. Harmele b. Sinân, Dîvânu'ş-Şemmâh b. Żirâr ez-ZZ̈̈byânî, thk. Selâhüddîn el-Hâdî (Kahire: Dâru'l-Maârif, 1968), 139; Cerîr, Dîvânu Cerîr bi şserhi Muhammed b. Habîb, 1/422; 2/534; Ebû Firâs Hemmâm b. Gālib b. Sa'saa Ferezdak, Dîvânu'l- Ferezdak, thk. Ali Fấûr (Beyrut: Dâru'l-Kütübi'l-illmiyye, 1407/1987), 297; Umeyr b. Şüyeym b. Amr el-Kutâmî, Dîvânu'l-Kuțâmî, thk. İbrahim es-Sâmirâî - Ahmed Matlub (Beyrut: Dâru's-Sekâfe, 1960), 120; İliyyâ elHâvî, Şerḥu Dîvâni'l-Ferezdak, 1/558; Ebû Osmân Amr b. Bahr el-Câhiz, Rasẩilül'-Câhiz, thk. Abdüsselâm Muhammed Hârûn (Kahire: Mektebetü'l-Hânecî, 1384/1964), 1/207, 208; İbn Fâris, Mu'cemü mekāyîsi'lluġa, 2/195; 3/461; Ebû Ubeyde el-Bekrî, Mu'cemü me'sta'cem, 2/422; 2/694; İbn Manzûr, Lisânü'l-'Arab, "hużż", 4/246.

25 Ebü'l-Feth Mahmûd b. el-Hüseyn Küşâcim, Dîvânu Küşâcim, thk. Nebevî Abdülvâhid Şaclân (Kahire: Mektebetü'l-Hâncî, 1417/1997), 413.

26 Ebû Osmân Amr b. Bahr b. Mahbûb el-Câhiz, Kitâbü'l-Hayevân, thk. Abdüsselâm Muhammed Hârûn (Kahire: Matbaatu Mustafa el-Bâbi'l-Halebî, 1385/1965), 5/58. 
görünürlüğ̈̈ onunla kapatılamaz demeye getirmiştir. Dolayısıyla Câhiz’a göre görünümü başka renklerle kapatılamayan ama başka renklerin görünümünü değiştirebilen tek renk siyahtır ki bu, Câhiz'in, tüm renk tonlarını somut şeyler üzerinden değerlendirdiğini göstermektedir. Dil ve edebiyat âlimi İbn Fâris'in (öl. 395/1004)

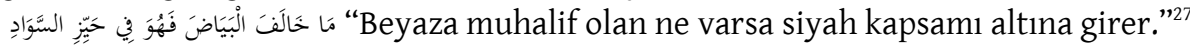
tarzındaki açıklaması da kapsam alanının genişliğiyle tartı̧̧maya açıktır.

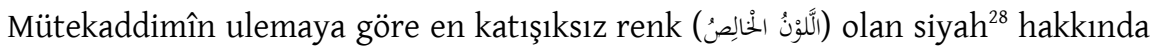
belki de en dikkat çekici açıklamayı Zâhirî mezhebinin en önemli savunucularından biri olan İbn Hazm (öl. 456/1064) yapmıştır. Işık ve görme eylemi üzerinden 'siyah' (سواد) diye bir rengin bulunmadığını iddia eden İbn Hazm, göz mekanizması içinde bulunan karanlığın somut bir ışıkla temasının kesilmesi sonucunda körlüğün oluştuğunu hissîni delil olarak sunar. Çünkü ona göre siyah demek aslında karanlık demektir. Başka bir ifadeyle siyah ve karanlık tamamılla aynı şeyi karşılayan iki olgudur. Bundan dolayı İbn Hazm karanlığın gözle görülmeyen bir varlık olduğunu öne sürerek siyahlığ1 da bu görüş üzerinden değerlendirmektedir.

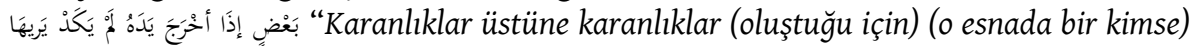
elini çıkarsa neredeyse onu bile göremez." ${ }^{\prime 3}$ âyetini ise sahip olduğu bu görüşü kanttlamak için sunar. Binâenaleyh kendisine göre bir karga ya da karşılaşılan bir Zenciye siyah denilmesi mecazdan öteye geçmeyen bir algidır. ${ }^{31}$

İbn Hazm'ın bu yaklaşımı zahiri öğretilerle ilişkilendirilebildiği gibi renkleri, "cisimlerin etrafa yaydığı 1şığın gözlerle algılanması veya ışığın cisimler üzerindeki yayılma çeşitliliği ve potansiyelinden oluşan görsel bir duyum" şeklinde tanımlayan felsefi bakış açısı üzerinden de okunabilir. ${ }^{32}$ İbn Sînầya (öl. 428/1037) nispet edilen r.Maddede bilfiil belirgin hâle gelen renk, ancak ışığın ondaki varlığıyla ortaya çıkar. Bu yüzden karanlıkta ışık bulun-

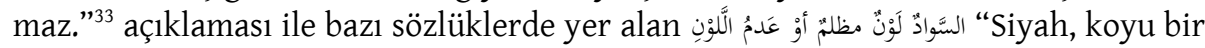
renktir ya da renksizliktir." şeklindeki tanım bu yaklaşımı teyit etmektedir. ${ }^{34}$

\subsection{Siyah Renk Anlamında Kullanılan Sözcüklerin Pekiştirilmesi}

27 İbn Fâris, Mu'cemü mekāyîsi'l-luġa, 2/195.

28 Ebû Ca'fer Nasîrüddîn Muhammed b. Muhammed b. el-Hasen et-Tûsî, Telhîșï’l-Muhașșal el-ma'rûf bi Naḳdi'l-Muhașșal (Beyrut: Dâru'l-Edvâ', 1405/1985), 143.

29 Ebû Muhammed Alî b. Ahmed b. Saîd b. Hazm İbn Hazm, el-Faṣl fi'l-milel ve'l-ehvâ’ ve'n-nihal (b.y: Mektebetü's-Selâmi'l-Alemiyye, ts.), 5/88, 89.

30 Kuranmeali.com (Erişim 6 Nisan 2021), en-Nûr 24/40.

31 İbn Hazm, el-Fașl fi'l-milel ve'l-ehvâ' ve'n-nihal, 5/88, 89.

32 Aydın Topaloğlu, "Renk”, Türkiye Diyanet Vakfi İslâm Ansiklopedisi (Erişim 24 Kasım 2020).

33 Ebü'l-Fazl Adudüddîn Abdurrahmân b. Ahmed b. Abdilgaffâr el-Îcî, el-Mevâkııffí 'ilmi'l-kelâm (Beyrut: Âlemü'l-Kütüb, 2005), 132, 133; Muhammed Aclâ b. Alî b. Muhammed Hâmid et-Tehânevî, Keşşâfü ıșțlâhâti'l-fünûn ve'l-'ulûm, thk. Ali Dahrûc (Beyrut: Mektebetu Lübnan, 1996), 2/1418.

34 Butrus b. Bûlus el-Bustânî, Muhîțï'l-Muhîț (Beyrut: Dâiretü'l-Maâcim Mektebetu Lübnan, 1987), 439. 
Arap dilinde siyahlı̆̆ın belirgin kılınması ya da siyah bir unsura daha fazla dikkat çekilmesi için kullanılan sözcükler oldukça fazladır. Nitekim belirtilmek istenen siyahlığın türü, farklı tonları ve çeşitli nesnelere özgü oluşu أسنوَد veya türevleriyle bir-

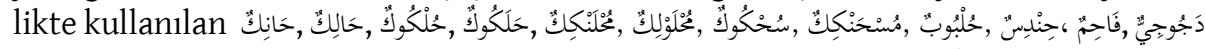

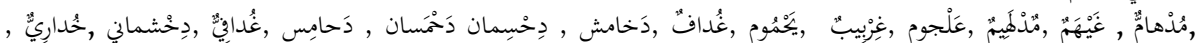

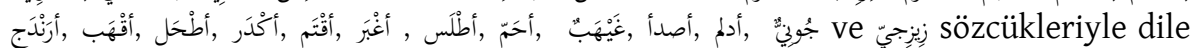
getirilir.

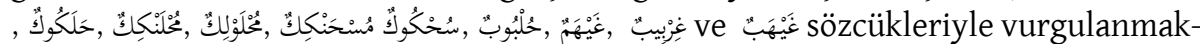
tadır. ${ }^{36}$ Arap dili ve edebiyatı âlimi Ebû Mansûr es-Seâlibî̀nin (öl. 429/1038) sadece insanların nitelenmesinde kullanılmak üzere siyahın açıktan koyuya doğru renk to-

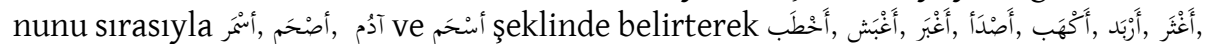

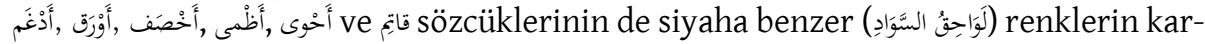
şılanmasında kullanıldığını belirtmesi de bu minvalde değerlendirilebilir. ${ }^{37}$

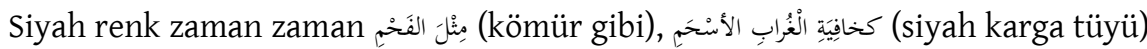
ve مثرُ حالِكة الُْرُربِ (karganın gagası gibi) ifadelerle de pekiştirilmiştir. ${ }^{38}$ Öte yandan karanlık, sevgili ve onun güzellik unsurları ile koyu bir deri rengine sahip olan canlılar

35 Ebû Amr İshâk b. Mirâr eş-Şeybânî, Kitâbü'l-Cîm, thk. İbrahim el-Ebyârî - Abdülalîm et-Tahâvî (Kahire: el-Hey'etü'l-Âmme li Şuûni'l-Metâbici'l-Emîriyye, 1294/1974), 2/62; İbnü's-Sikkît, Kitâbü'l-Elfâz, 152, 153; Ebü'l-Ferec Kudâme b. Caffer el-Bağdâdî, Cevâhirü'l-elfâz, thk. Muhammed Muhyiddin Abdülhamîd (Kahire: y.y. 1350/1932), 430, 431; Ebû Alî İsmâ̂ll b. el-Kāsım b. Ayzûn el-Kālî, Kitâbü'l-Emâlî ve'zzeylu ve't-tenbîh (Misır: el-Hey’etül-Misriyyetü'l-Âmmetu li'l-Kitâb, 1975), 1/59, 60; İbn Sîde, elMuhașsaș, 2/104, 105; Ebû Bekr Muhammed b. el-Kāsım b. Muhammed İbnü'l-Enbârî, Şerhư'l-Kasââidid'sseb 'i'ț-țtvâli'l-Câhiliyyât, thk. Abdüsselâm Muhammed Hârûn (Kahire: Dâru'l-Maârif, ts.), 62; Ebû Gālib Muhammed b. el-Mübârek b. Muhammed İbn Meymûn, Müntehe't-țaleb min eş'âri'l-'Arab, thk. Muhammed Nebîl Turayfî (Beyrut: Dâru Sâdır, 1999), 2/363.

36 Ebû Muhammed Sâbit b. Ebî Sâbit Saîd el-Kûfî el-Lugavî, Halku'l-insân, thk. Abdüssettâr Ahmed Ferrâc (Kuveyt: Matbaatu Hukûmeti Kuveyt, 1985), 85, 86.

37 Ebû Mansûr Abdülmelik b. Muhammed b. İsmâîl es-Seâlibî, Fiḳü̈l-lug̉a ve sırrü'l-‘Arabiyye, haz. Yasin el-Eyyûbî (Beyrut: el-Mektebetü'l-Asriyye Seydâ, 1420/2000), 126, 127.

38 Antere b. Şeddâd b. Amr el-Absî, Dîvânu 'Antere, thk. Muhammed Saîd Mevlevî (Kahire: el-Mektebetü'lİslâmî, 1390/1970), 193; Ebû Ca'fer Ahmed b. Muhammed b. İsmâîl en-Nehhâs, Şerhu'l-kasââidi't-tis'i'lmeşhûrâti'l-mevsûmeti bi'l-Mu'allakāt nşr. Ahmed Hattâb (Bağdat: Dâru'l-Hurriye li't-Tabbâa, 1393/1973), 2/4470; Ezherî, Tehzî̉bü'l-luġa, “tanb”, 13/368; Ebü'l-Hasen Alîb. İsmâîl İbn Sîde, el-Muhkem ve'l-muhîtụu'l-a'zam, thk. Mustafa es-Sekkā vd. (Kahire: Ma'hedü'l-Mahtûtât bi Câmiati'l-Lügati'l-Arabiyye, 1393/1973),", “faḥm”, 3/392; “ḥaleke”, 3/41; Ebû Abdillâh Hüseyn b. Ahmed ez-Zevzenî, Şerḥu’Mu'allakāti's-sebc, thk. Komisyon (Beyrut: ed-Dâru'l-Âlemiyye, 1413/1992), 132. 
teşbih ve mecazlar üzerinden genel olarak 22

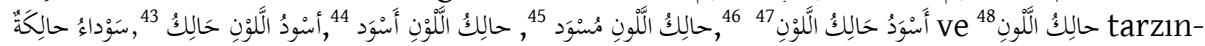
daki ifadelerle açıklanmaya çalışılmıştır.

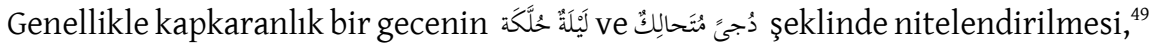

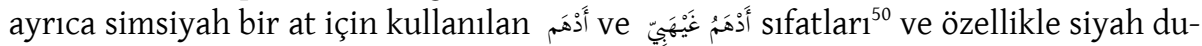
man için kullanılan tabiri ${ }^{51}$ siyah rengin pékiştirilmesi hususunda zikredilen sözcüklerin ancak belirli nesne ve varlıkların nitelenmesinde kullanılmaları gerektiğini düşündürüyorsa da bu isabetli görünmemektedir. Nitekim Kitâbü'l-Fașị̂ adlı eserinin

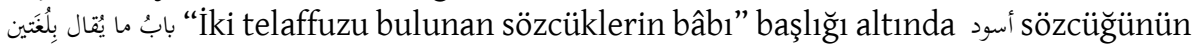
hem حانك hözcükleriyle vurgulanabileceğini söyleyen Sa'leb (öl. 291/904)

39 Nemerî, Kitâbü'l-Mülemma , 62; İbnü'l-Enbârî, Şerḥu'l-Kașẩidi’s-seb'i'ț-țıvâli'l-Câhiliyyât, 62.

40 Ebü'l-Musabbih Abdurrahmân b. Hâris A'şâ Hemdân, Dîvânu A'şâ Hemdân ve ahbâruh, thk. Hasan Îsâ Ebû Yâsîn (Riyad: Dâru'l-Ulûm, 1403/1983), 92.

${ }^{41}$ Ebû Basîr Meymûn b. Kays b. Cendel el-Bekrî Acşâ el-Kebîr, Dîvânu el-A`şâ el-Kebîr, thk. Muhammed Hüseyin (b.y: Mektebetü'l-Âdâb el-Matbaatu'n-Numûzeciyye, 1950), 77.

42 Şemmâh, Dîvânu'ş-Şemmâh b. Żirâr ez- Zü̈byânî, 78.

43 Ebû İshâk İbrâhîm b. Muhammed b. Ahmed İbn Ebû Avn, Kitâbü't-Teşbîhât, nşr. Muhammed Abdülmuîd Hân (London: Câmiatu Cambridge, 1369/ 1950), 219.

${ }^{44}$ Hufâf b. Nüdbe b. Umeyr el-Hâris, Şicru Hufäfb. Nudbe es-Sülemî, thk. Nuri Hammûdî el-Kaysî (Bağdad: Matbaatu'l-Maârif, 1968), 66; Ebû Mâlik Giyâs b. Gavs b. es-Salt el-Ahtal, Dîvânu el-Ahțal, haz. Mehdî Muhammed Nâsıruddîn (Beyrut: Dâru'l-Kütübi'l-ílmiyye, 1414/1994), 219.

45 Ebû Amr Düreyd b. es-Simme, Dîvânu Düreyd b. eș-Șımme, thk. Ömer Abdürresül (Beyrut: Dâru'l-Maârif, ts.), 64; Ebû Saîd Abdülmelik b. Kureyb el-Asmaî, el-Așmaciyyât, thk. Ahmed Muhammed Şâkir - Abdüsselâm Hârûn (Beyrut: y.y. 1375/1955), 109; Ebû Alî Ahmed b. Muhammed b. el-Hasen el-Merzûkī, Şerḥu Dîvâni'l-Hamâse, haz. Ğarîd eş-Şeyh - İbrahim Şemsüddîn (Beyrut: Dâru'l-Kütübi'l-İlmiyye, 1434/2003), $2 / 579$.

46 Ebü'l-Kāsım Alî b. el-Hasen b. Hibetillâh b. Abdillâh İbn Asâkir, Târîhu medîneti Dımaşk, thk. Ebû Saîd Ömer b. Garâme el-Amrevî (Beyrut: Dâru'l-Fikr, 1415/1995), 17/235; İbn Meymûn, Müntehe'ț-taleb min eş'âri'l-'Arab, 3/331.

${ }^{47}$ Ebû Alî el-Muhassin b. Alî b. Muhammed el-Kādî et-Tenûhî, Nişvârü'l-muhâạara ve ahbârü'l-müzâkere, nşr. Abbûd eş-Şâlcî (Beyrut: Dâru Sâdır, 1995), 5/39.

48 Ebû Mansûr Abdülmelik b. Muhammed b. İsmâ̂̂l es-Seâlibî, Yetîmetü'd-dehr fî mehâsini ehli'l-'așr, nşr. Müfîd Muhammed Kumeyha (Beyrut: Dâru'l-Kütübi'l-ìlmiyye, 1403/1983), 4/208.

49 Ebû Amr Tarafe (Amr) b. el-Abd el-Vâilî, Dîvânu Țarafe b. el-‘Abd, haz. Mehdî Muhammed Nâsırüddin (Beyrut: Dâru'l-Kütübi'l-i̇lmiyye, 1423/2002), 60; Cerîr b. Atıyye b. el-Hatafâ et-Temîmî, Dîvânu Cerîr bi şerhi Muhammed b. Habîb, thk. Numan Muhammed Emin Taha (Kahire: Dâru'l-Maârif, ts.), 1/75; Ebü'lHasan Ali b. Muhammed et-Tehâmî, Dîvânu Ebi'l-Hasan Ali b. Muhammed et-Tehâmî, thk. Muhammed Abdurrahman er-Rabî‘ (Riyad: Mektebetü'l-Maârif, 1402/1982), 248.

50 Ebü'l-Abbâs Şihâbüddîn Ahmed b. Abdilvehhâb b. Muhammed en-Nüveyrî, Nihâyetü'l-ereb fi fünûni'ledeb, thk. Müfîd Kamîha (Beyrut: Dâru'l-Kütübi'l-İlmiyye, 1424/2004), 10/6; Ebü'l-Abbâs Şihâbüddîn Ahmed el-Kalkaşendî, Șubhu'l-a'şâ fî șınâ'ati'l-inşâ (Kahire: Dâru'l-Kütübi'l-Misriyye, 1340/1922), $2 / 18$.

51 Nemerî, Kitâbü'l-Mülemma', 66. 
bu vurgunun belirli bir nesneyle kayıtlı olması gerektiğine değinmemiștir. ${ }^{52}$ Böylece Sa'leb'e göre istisna gözetilmeksizin siyah olan şeyler حالك ve vözcükleriyle nitelendirilip pekiştirilebilir. ${ }^{53}$ Klasik Arap şiirinde atın donları, gecenin karanlığı ve doğaya dair bazı betimlemelerde yukarıda yer verilen sözcüklerin kullanılması ${ }^{54}$ dikkate alındığında Sa'leb'e ait görüşün daha isabetli olduğu ileri sürülebilir.

\section{Siyah Rengin Anlam Boyutu}

Bu başlıkla, herhangi bir konuşma veya yazıda birden fazla kullanılan bir sözcük veya ifadeye geleneksel kültürle birlikte diş dünyadaki nesnelerden yola çıkılarak farklı anlamların yüklenmesi kast edilmiştir. Örneğin bir olgu bu bakış açısıyla ele alındığı zaman o olguya dair sözcüklerin ne etimolojik tahlilleri ne de çeşitli türevlerine yer verilmeden sadece anlam farkındalığına yönelik birtakım tespitlerde bulunulur. Dolayısıyla siyah renk bu ana başlığın alt başlıkları altında sadece bu açıdan incelenmeye çalışılacaktır.

\subsection{Siyah Renge Farklı Anlamların Yüklenmesi}

Siyah rengi karşılayan sözcüklere farklı anlamların yüklenmesinde Arap toplumunda karşılaşılan yöre kültürünün izleri bariz bir şekilde görülmektedir. Nitekim Hîre Hükümdarı Amr b. Hind'i meşhur kasidesinde öven muallaka şairlerinden Ebû Ubeyde Hâris b. Hillize el-Yeşkürî (öl. 570), فَهَداهُمْ بِالأسوَدَيْنِ Amr b. Hind (cenk esnasinda) onları (kendi kavmini) kurtard.$^{55}$ derken iki siyah olarak belirttiği الأسْوَيَّْن ile su ve hurmayı kast etmiştir. Aynı anlam zaman zaman Arap toplumu tarafindan kullanılan Biz kırmızı et ve şarabı değil, su ve hurmayı benimseyen-

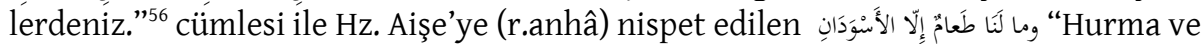

52 Ebü’l-Abbâs Ahmed b. Yahyâ b. Zeyd eş-Şeybânî Sa'leb, Kitâbü'l-Fașîh, nşr. Von Barth (Leipzig: y.y. 1876), 44.

53 Ebû Muhammed Abdullah b. Ca'fer İbn Dürüsteveyh, Tașhîhu'l-Fașîh, thk. Muhammed Bedevî elMahtûn - Ramazan Abdüttevvâb (Kahire: Metâbiu't-Ticâriyye, 1425/2004), 477.

54 İmruülkays, Dîvânu İmri’i'l-Kays ve mulhaḳâtuh bi şerhi Ebî Saîd es-Sükkerî, 1/306; Ebû Kâcb Temîm b. Übey b. Mukbil b. Avf el-Aclânî İbn Mukbil, Dîvânu İbn Mukbil, thk. İzzet Hasan (Beyrut: Dâru'ş-Şarki'l-Arabî, 1416/1995), 201; Âmir el-Hâris b. Kelefe Cirân el-Avn en-Numeyrî, Dîvânu Cirâni'l-avd en-Numeyrî, thk. Karîn Sâdır (Beyrut: Dâru Sâdır, 1999), 107; Ferezdak, Dîvânu'l- Ferezdak, 297; Ebû Muâz Beşşâr b. Bürd el-Ukaylî, Dîvânu Beşşâr b. Bürd, nşr. Muhammed et-Tâhir b. Âşûr (Cezair: Vizâretü'l-Evkâf, 2007), 1/326; Câhiz Kitâbü'l-Hayevân, 3/429; Ebû Saîd el-Hasen b. el-Hüseyn b. Ubeydillâh es-Sükkerî, Dîvânu Ebi'l-Esved ed-Dü'elî, thk. Muhammed Hasan Âl Yâsîn (Beyrut: Dâru Mektebeti'l-Hilâl, 1418/1998), 77; İliyyâ el-Hâvî, Şerhu Dîvâni'l-Ferezdak (Beyrut: Dâru'l-Kütübi'l-Lübnânî Mektebetü'l-Medrese, 1983), 1/558; Nüveyrî, Nihâyetül-ereb, 10/5-7.

55 Ebû Ubeyde el-Hâris b. Hillize b. Mekrûh el-Bekrî, Dîvânu el-Hâris b. Hillize, haz. Emîl Bedî‘ Ya'kūb (Beyrut: Dâru'l-Kitâbi'l-Arabî, 1411/1991), 30.

56 Ebü'l-Kāsım Mahmûd b. Ömer ez-Zemahşerî, Esâsü'l-belaġa, thk. Muhammed Bâsil Uyûn es-Sûd (Beyrut: Dâru'l-Kütübi'l-i̇lmiyye, 1419/1998), 1/212; Zebîdî, Tâcü'l-‘arûs, "humr", 11/75. 
su dışında yiyeceğimiz yoktu. ${ }^{57}$ ifadesinden de kast edilmiştir. ${ }^{58}$

Her ne kadar siyah rengin ikil kalıbıyla hurma ve suya ad yapılmasını tevile muhtaç gören araştırmacılar olsa $\mathrm{da}^{59}$ bu adlandırmanın klasik dönem şiir dizeleri ve neredeyse tüm muteber sözlüklerde açık bir şekilde yer alması bu konuda yargı belirten ifadelerden kaçınılmasını elzem kılmaktadır. Zira söz konusu adlandırmanın Arap kültürüyle ilişkilendirilebilecek bir tarafının olduğunu söylemek zorlama bir yorum olmayacaktır. Biraz daha açacak olursak suyun أسود sözcüğü ve türevleriyle nitelendirilerek hurma ile birlikte ortak bir ad şeklinde telaffuz edilmesi Arap Yarımadası'na özgü bir hitabet tarzı olmaktan ziyade yöre kültürünün zeminini hazırladığı bir adlandırma olarak değerlendirilebilir.

Suyun daha çok berrak, hurmanın ise siyaha çalan koyu bir renginin olduğu aşikârdır. Bu durumda الأَمْوَدَاِِ sözcüğüyle birinin diğerinden ayrı düşünülemeyeceği iki unsurun tek renk altında birleştirilerek ifade edilmeye çalışılması şu şekilde izah edilebilir: Arabistan yarımadası oldukça sıcak ve kurak kuşakta yer aldığı için özellikle yaz aylarında tahammülü zor olan bir iklim baş gösterir. ${ }^{60}$ Hurma da Arabistan yarımadasında yer alan bütün vahaların en gözde ağacı konumundadır. ${ }^{61} \mathrm{Bu}$ durumda etrafında hurma bahçelerinden başka bir şey göremeyen toplumdaki her bir ferdin sürekli tükettiği hurma su içmeyi de zorunlu kılmaktadır ki bu, biri gıda diğeri sıvı ihtiyacını karşılayan iki nimetin yan yana zikredilme nedenini anlaşılır kılmaktadır." Bu yüzden belagat ilminde "Tağlîb Sanatı"62 olarak değerlendirilen bu tür ifade tarzlarının doğrudan coğrafi koşullar ve yöredeki kültürle bir bağının olduğunu söylemek yanlış olmayacaktır. İftarın, hurma bulunmadığı takdirde su ile açılmasını tavsiye eden hadis-i şerif de bu iki nimetin yöre kültüründeki birlikteliğini göstermesi açısından zikredilmeye değerdir. ${ }^{63}$

57 Ezherî, Tehzîbü'l-luġa, “sâde”, 13/33; Ebü’l-Ferec Cemâlüddîn Abdurrahmân b. Alî İbnü'l-Cevzî, Garîbü'l-ḥadîs, nşr. Abdülmu`tî Emîn Kal'acî, (Beyrut: Dâru'l-Kütübi'l-i̇lmiyye, 1425/2004), 1/507.

58 Ebû Zeyd Saîd b. Evs b. Sâbit el-Ensârî, Kitâbü’n-Nevâdir fi'l-luġa, thk. Muhammed Abdülkādir Ahmed (Beyrut: Dâru'ş-Şurûk, 1401/1981), 307; Ezherî, Tehzîibül-luġa, "sâde”, 13/33; İbn Manzûr, Lisânü'l'Arab, "sevede", 3/227. Câhiliye dönemi şairlerinden Ubeyd b. el-Ebras'ın siyah bir balinayı tasvir ettiği kasidesinin bir beytinde suyun rengi أسْوَد olarak nitelenmiştir. bk. Ubeyd b el-Ebras b. Avf el-Esedî, Dîvânu 'Ubeyd b. el-Ebraș, thk. Eşref Ahmed Adare (Beyrut: Dâru'l-Kitâbi'l-Arabî, 1414/1994), 74.

59 Soner Gündüzöz, “Kur'ân'da Renklerin Büyülü Gücü Semiotik Bir İnceleme”, EKEV Akademi Dergisi, 16 (2003), 81.

60 Kudret Büyükcoşkun, “Arabistan”, Türkiye Diyanet Vakfi İslâm Ansiklopedisi (Erişim 16 Temmuz 2021).

61 Büyükcoşkun, “Arabistan”.

${ }^{62}$ Tağlîb, aralarındaki ilgi münasebetiyle iki şeyden birinin diğerine tercih edildikten sonra tercih edilen şeyin lafzının her ikisi için kullanılması demektir. bk. Ebü'l-Hasen Alî b. Muhammed b. Alî es-Seyyid eş-Şerîf el-Cürcânî, et-Ta'rîfât, haz. Muhammed Bâsil Uyûn es-Sûd (Beyrut: Dâru'l-Kütübi'l-ïlmiyye, 1424/2003), 66.

63 Hurma bulunmadığı takdirde orucun su ile açılmasını tavsiye eden hadis için bk. Ebû Abdillâh Muhammed b. Yezîd Mâce el-Kazvînî İbn Mâce, Sünenü İbn Mâce, nşr. Muhammed Nâsırüddîn el-Elbânî 
Câhiliye dönemi şairlerinden Nâbiga ez-Zübyânînnin (öl. 604) Onun evinin avlusunda kesimlik ve semiz develerin karkaslarını lokma haline getiren büyük bir siyah kazanı

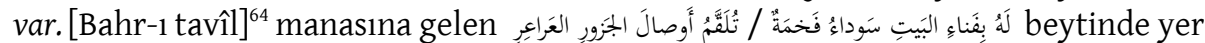
alan سوداء sözcüğü şairin övgüsüne muhatap olan kişinin cömertliğine kinaye yapilmıştır. Zira alt kısmı ve yan tarafları siyahlaşmış olan bir kazanda bir şeylerin pişirildiği sonucu çıkmaktadır ki bu da sıklıkla gelen misafirlere karşı saygıda kusur edilmediği ve ikramda bulunulduğunu göstermektedir.

Kûfe dil ekolünün önde gelen Arap dili ve edebiyatı âlimi Ebü'l-Abbâs Mufaddal

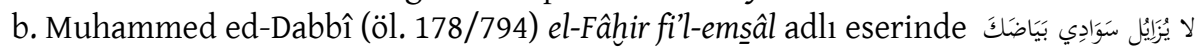

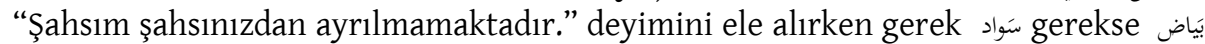
sözcüğünün "şahıs" anlamında kullanıldığını Basra dil ekolünün meşhur temsilcilerinden Ebû Saîd Abdülmelik b. Kureyb el-Asmâ̂’ye (öl. 216/831) dayandırır. ${ }^{65}$ Toplum

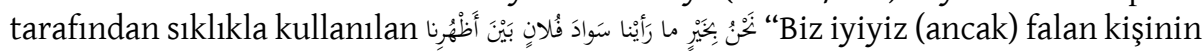
karartısını aramızda görmedik." ifadesinde de bu sözcük şahıs anlamında kullanılmıştır. ${ }^{66} \mathrm{Bu}$ durumda سوَاد sözcügüünün aslî anlamından koparıldığı söylenemez. Zira canlı olup olmamasına bakılmaksızın özellikle uzaktaki bir şeyin net olarak görülemediği ve tespit edilemediği durumlarda "Bir karartı (سواد) görüyorum." ifadesi ol-

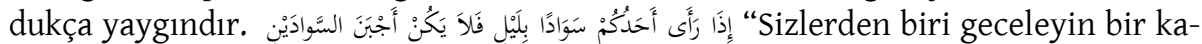
rartı gördüğünde (kendisi de bir karartı olarak görüldüğü için) iki karartının en korkağı olmasın." ${ }^{67}$ hadisinin yanı sıra çorak ve tarıma elverişsiz topraklarda yaşayan Arabistan sakinlerinin, fetih sebebiyle bulundukları bölgenin dışına çıktıklarında, bol miktarda ağaç ve yeşilliğe sahip olduğu için uzaktan bir karartı gibi görünen F1rat-Dicle havzasına سَوَاد demelerinden bu manaya ulaşmak mümkündür. ${ }^{68}$

\subsection{Siyah Renk İle Sevgiliye Yapılan İltifatlar}

Klasik Arap şiirinde siyah rengi karşılayan sözcüklerden biri olan sevâd sözcüğü terkibi şeklinde genelde platonik aşk, bireysel arzu ve özlemlerin mecazi dili yapılmıştır. Bu manada muallaka şairlerinden Antere b. Şeddâd'ın (öl. 614) يا عبلَ أنبِ Ex Able! Ey son arzu! Sen kalbinin derinliklerindesin;

(Riyad: Mektebetü’l-Maârif, ts.), “Ṣıâm” 297 (No. 1699).

64 Ebû Ümâme Ziyâd b. Muâviye Nâbiga ez-Zübyânî, Dîvânu en-Nâbiga ez-Zübyânî, haz. Muhammed etTâhir İbn Âşûr (Cezayir: eş-Şerîketü'l-Vataniyye li'n-Neşr ve't-Tevzî‘', 1976), 113.

65 Ebü'l-Abbâs Mufaddal b. Muhammed ed-Dabbî, el-Fâhir fi'l-emsâl, haz. Muhammed Osman (Beyrut: Dâru'l-Kütübi'l-İlmiyye, 2011), 152, 153; Ebû Bekr Muhammed b. el-Kāsım b. Muhammed İbnü'lEnbârî, ez-Zâhir fi me ânî kelimâti'n-nâs, thk. Hâtim Sâlih ed-Dâmin (Beyrut: Müessesetü'r-Risâle, 1412/1992), 1/241; Ezherî, Tehzî̉bü'l-luġa, "sâde", 13/30.

66 Câhiz Kitâbü'l-Hayevân, 3/247.

67 Ebü'l-Kāsım Mahmûd b. Ömer ez-Zemahşerî, el-Fẩik fí garîbi'l-hadị̂s, thk. Ali Muhammed el-Bicâvî Muhammed Ebü'l-Fazl İbrâhim (Kahire: Matbaatu Îsâ el-Bâbi'l-Halebî ve Şurekâuh, ts.), 2/211.

68 Ebû Zeyd el-Ensârî, Kitâbü'n-Nevâdir fi'l-luġa, 598; Yâkūt b. Abdillâh el-Hamevî, Mu'cemü'l-büldân, $3 / 309$. 
(hadi) ruhuma hükmet ve insaflı ol. [Bahr-1 basît] ${ }^{69}$ şeklinde ifade ettiği beytinde bu terkip şairin kara sevdaya dönüşen umutsuz ama güçlü aşkının nişanesi sayılmıştır.

Muhadram şairlerden Kays b. Abdillâh b. Rebîa en-Nâbiga el-Ca'cî de (öl. 65/685) Gönlümün derinliklerine düştü O. Ne başkasını isterim ne de onun sevmekten vazgeçerim. $[\mathrm{Bahr}-1 \text { tavîl] }]^{70}$ anlamındaki beytinde içindeki sevgisini bir nevi kalbin akla hâkimiyeti üzerinden aynı terkiple (isim tamlaması) ifade etmiştir. ${ }^{71}$ Keza Emevîler dönemi şairi ve Mecnûn lakaplı Kays b. el-Mülevvah

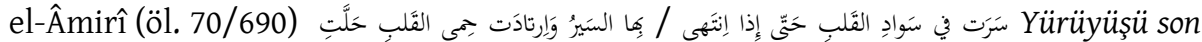
bulana kadar kalbi(mi)n derinliklerine dalarak gezindi ve sığınıklarını çözdü. [Bahr-1 tavîl] $]^{72}$ derken ruhuna işlemiş olduğu sevday1 سواد ve قلب sözcüklerini bir araya getirerek tasvir etmeye çalışmıştır.

İlgili başlık Cemîl Buseyne el-Uzrî (öl. 82/701), Ahtal (öl. 92/710-11) ve Beşşâr b. Bürd (öl. 167/783) tarafından söylenen ve aşağıda yer verilen beyitlerle sonlandırılacaktır. Zira Arap edebiyatının çeşitli evlerinden, kimi şairlerin aynı gerekçelerle inşâd ettikleri beyitlerden bolca örneklerin sunulması her zaman imkân dâhilindedir.

Ebû Amr Cemîl b. Abdillâh b. Ma'mer el-Uzrî:

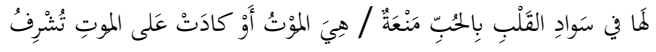

Onun için sevgi ile alakalı kalbin derinliklerinde bir direnç vardır. O direnç ya ölümdür ya da ölümün eşiğinde olmaktır.

$[\text { Bahr-1 tavil }]^{73}$

Ebû Mâlik Glyâs b. Gavs el-Ahtal:

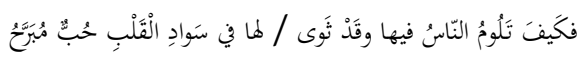

Kalbin en derininde şiddetli bir sevgi yerleştiği halde ona karşı insanlar (beni) nasıl kınayabilir? $[\text { Bahr-1 tavîl] }]^{74}$

${ }^{69}$ Ebû Zekeriyyâ Yahyâ b. Alî b. Muhammed el-Hatîb et-Tebrîzî, Şshhu Dîvâni 'Antere, haz. Mecîd Tarrâd (Beyrut: Dâru'l-Kitâbi'l-Arabî, 1412/1992), 136.

70 Ebû Leylâ Kays b. Abdillâh b. Rebîa en-Nâbiga el-Ca'dî, Dîvânu'n-Nâbig̉a el-Ca'dî, thk. Vâdih es-Samed (Beyrut: Dâru Sâdır, 1998), 186.

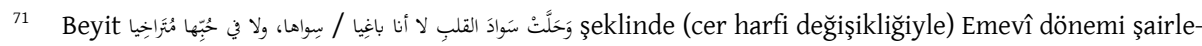
rinden Zürrumme el-Kahtânî ye de (öl. 117/735) nispet edilmiştir. bk. Ebü'l-Hâris Zürrumme Gaylân b. Ukbe b. Ma'dî b. Amr, Dîvânu Zürrumme, haz. Ahmed Hasan Besec (Beyrut: Dâru'l-Kütübi'l-İlmiyye, 1415/1995), 292.

72 Davûd b. Ömer el-Entâkî, Tezyînü'l-esvâk bi tafṣ̂li eşvâki'l-'uşsâk, thk. Emîn Abdülcâbir el-Buhayrî (Kahire: Dâru'l-Beyâni'l-Arabî, ts. ), 1/185.

73 Ebû Amr Cemîl b. Abdillâh b. Ma'mer el-Uzrî, Dîvânu Cemîl Buseyne, nşr. Butrus el-Bustânî (Beyrut: Dâru Beyrut, 1402/1982), 32.

74 Ahtal, Dîvânu el-Ahțal, 67. 
Ebû Muâz Beşşâr b. Bürd:

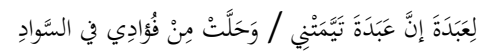

Abede’ye (söylüyorum). Kesinlikle o aklımı başımdan aldı ve kalbimin derinliklerine yerlești. [Bahr-1 vâfîr $]^{75}$

İlk iki beyitte سواد ve قلب sözcükleri doğrudan bir isim tamlaması şeklinde kullanılmışken diğerinde isim tamlamasından kast edilen aynı anlam cer harfleri vasıtasıyla vurgulanmaya çalışılmıştır.

\subsection{Siyah - Beyaz Kombinasyonu}

Arap dilinde gerek gerçek gerekse sembolik ve mecâzi anlamların yüklendiği renk olan siyah en fazla beyaz renkle birlikte kullanılmıştır. Hatta hikmet içirikli sözler, şiir, deyim ve atasözleri üzerinden verilmek istenen mesajlar incelenirse birbirinin karşıtı olan bu renkler için 'biri diğerinin mütemmimi mahiyetinde kullanılmıştır' denilebilir. Bu sadette Arap toplumu nezdinde çaresizliği, sıkıntıyı, üzüntüyü ve acıyı sembolize eden siyah renk mutluluk duygularını harekete geçirip estetik algısını güçlendiren beyaz renk ile yan yana getirildiğinde yaşanılmış olan acı veya tatlı hayatın tasvir merkezli bir özetini önümüze koymaktadır. Örneğin zorluklara göğüs

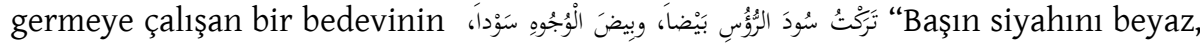
yüzün akını da kapkara bıraktım." demesi, tozpembe bir hayatın son bulduğunun itirafiyken; “Nasılsın?” sorusuna “Siyah olarak kalmasını isteğim şey beyazlaştığı gibi beyaz olarak kalmasını istediğim şey de siyahlaştı." şeklinde verilen cevap geride bırakılan bir ömrün ardından gençliğe duyulan çaresiz bir özlemin dile getirilmesidir. ${ }^{76}$

Gecelerin tasviri, uzunluğu ve âşıklar üzerindeki olumsuz etkisini defalarca şiir-

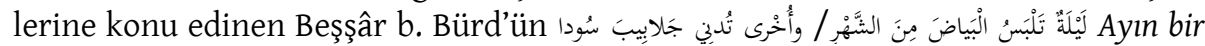
gecesi beyazlara diğeri siyahlara bürünüyor. [Bahr-1 hafif] ${ }^{77}$ beyti ile Zühde dair yazdığ

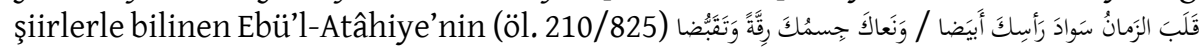
Zaman başındaki siyahlığı beyaza çevirdi, bedenin zayıfladığını ve büzüldüğünü haber verdi. [Bahr-1 tavîl] ${ }^{78}$ beytinde siyah ve beyaz renkler yan yana kullanılarak hayatın zorlukları ve beraberinde getirdiği çöküntü oldukça sade bir üslûpla anlatılmıştır.

75 Ebû Muâz Beşşâr b. Bürd el-Ukaylî, Dîvânu şi'ri Beşşâr b. Bürd, thk. es-Seyyid Bedrüddîn el-Alevî (Beyrut: Dâru's-Sekâfe, 1981), 94; Ebü'l-Ferec Alî b. el-Hüseyn b. Muhammed b. Ahmed el-Kureşî el-İsfahânî, elĖ̉ānî (Beyrut: Dâru İhyâi't-Türâsi'l-Arabî, 1415/1994), 6/453.

76 Ebû Ömer Şihâbüddîn Ahmed b. Muhammed İbn Abdürabbih, el-íkdüll-ferîd, thk. Müfîd Muhammed Kamiha - Abdülmecîd et-Terhînî (Beyrut: Dâru'l-Kütübi'l-i̇lmiyye, 1404/1983), 4/10; Merzûkī, Şerḥu Dîvâni'l-Hamâse, 2/663.

77 Beşşâr b. Bürd, Dîvânu Beşşâr b. Bürd, 2/137.

78 Ebû İshâk İsmâîl b. el-Kāsım b. Süveyd Ebü'l-Atâhiye, Dîvânu Ebi'l-'Atâhiye (Beyrut: Dâru Beyrut, 1406/1986), 240. 
Siyah ve beyaz rengi birlikte kullanan şahsiyetlerden bir diğeri şair ve Arap dili âlimi olan İbn Düreyd el-Ezdî'dir (öl. 321/933). İki yüz küsur beyti bulunan "elMakṣûretü'd-Düreydiyye” adlı kasidesinde طُّنَ rüyorsun! Karanlık gecenin ardından gelen sabahın aydınlığına benzeyen saç(lar)ımı. mana-

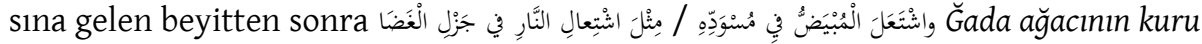
odununda tutuşan ateş gibi siyahlar arasında görünüveren aklarını. [Bahr-1 recez $]^{79}$ diyen İbn Düreyd siyah ve beyaz sözcüklerin ism-i fâil kiplerini kullanarak kendisine peyderpey beliriveren yaşlılık emarelerine atıfta bulunmuştur.

Gerek yaşlılığın gerekse gece ve gündüzün tasvirlerinde çok fazla kullanılan siyah

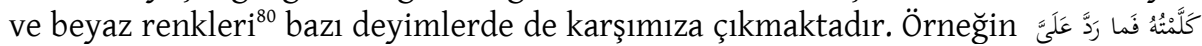
سموْداءَ ولا بَيْضاءَ "Onunla konuştum; fakat (kendisi) iyi veya kötü (herhangi) bir karş1lik vermedi." ${ }^{\prime 1}$ deyiminde أسوَّد sözcügüünün müennesi olan سَوْداء sözcüğü, beyaz renk için kullanılan sözcükle birlikte iletişim kurma noktasında sıkıntı çeken birisine gösterilen tepkinin kinayesi yapılmış ve birçok farklı kültürde olduğu gibi beyaz renge olumlu siyaha ise olumsuz bir anlam yüklenmiştir. Siyah ve beyaz renklerin birlikte yer aldığı diğer bir deyim, bizi dış tezahürlerin ardında saklı olanı anlamaya sevk edip her hâlükârda tedbirli olmamızı ögüutleyen "Her beyaz şey yağ parçası olmadığ1

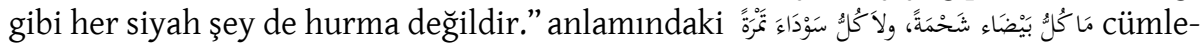
sidir. $^{82}$

\subsection{Olumsuzlukların Sembolü Olarak Siyah Renk}

Aslında siyah renk bazı Uzak Doğu ülkelerinde sevgi ve mutluluğun simgesi olarak görülmüssse de neredeyse diğer tüm kültürlerde benzeme ve benzetme amacıyla ölüm, yas, tasa, üzüntü, acı, keder ve uğursuzluk gibi birçok manada olumsuzluğun çağrımsal ifadesi yapılmıştır. Özellikle Arap kültüründe siyahlığa atfedilen olumsuzluklar hem çok yaygın hem de tabu haline gelmiştir. Bunun yanı sıra siyah kedi, siyah köpek, siyah yılan gibi birtakım hayvanlar kötü kehanetler ve yeraltı dünyasıyla da (cin-şeytan gibi) ilişkilendirilmiştir. ${ }^{83}$

79 Ebû Bekr Muhammed b. el-Hasen İbn Düreyd el-Ezdî, Makṣûretu İbn Düreyd, haz. İyd el-Vasif Muhammed (Dubai: Matbaatu Golden City, 2012), 44.

80 Ebü'l-Fazl Cemâlüddîn Muhammed b. Mükerrem İbn Manzûr, Nisârü'l-ezhâr fi'l-leyli ve'n-nehâr (Kostantiniyye: Matbaatu'l-Cevânib, 1298), 13-17.

81 Ezherî, Tehzî̉bü'l-luġa, "Humr”, 5/56; "sâde”, 13/35; İbn Sîde, el-Muhkem ve'l-muhîṭïl-a'zam, bîż”, 8/236; İbn Manzûr, Lisânü'l-'Arab, "sevede”, 3/225.

82 Ebü'l-Fazl Ahmed b. Muhammed b. Ahmed b. İbrâhîm el-Meydânî, Mecma'u'l-emsâl, thk. Muhammed Muhyiddin Abdülhamîd (Kahire: Matbaatu's-Sünneti'l-Muhammediyye, 1374/1955), 2/281; Merzûkī, Şerḥu Dîvâni'l-Hamâse, 1/115.

83 Câhiz, Kitâbü'l-Hayevân, 1/291; Muhammed Aceyne, Mevsû'atu esâtîiri'-'Arab 'ani'l-câhiliyyyeti ve delâletihâ (Beyrut: Dâru'l-Fârâbî, 1994), 2/200. Siyah renk Türkçe'de de eş anlamlısı sayılan kara sözcüğü vasıtasıyla kimi cesur ve atılgan kişilere lakap yapılması dışında genelde olumsuzluk için kullanılmaktadır. Zira bazı insanların karakter ve hissiyatlarındaki olumsuzlukları belirtmek üzere gözü kara, içi 
Siyah rengin en belirgin olumsuz çağrışımlarından biri ölenin cenazesinde bulunup belli bir süre yasını tutan yakın akrabaları ve sevenlerinin giydikleri elbiselerde göze çarpmaktadır. Bu durum Câhiliye dönemi şiirlerinde de sıklıkla dile getirilmiş, yaşanılan acı ve keder kıyafet üzerinden açığa vurulamaya çalışılmıştır. ${ }^{84}$ Ebû Hanîfe ed-Dîneverî̀nin (öl. 282/895), halifeliğin Abbasîlerde olması gerektiğini ilk dillendiren Ebû Abdillah Muhammed b. Ali b. Abdillah b. el-Abbas'ın (öl. 125/743) vefat haberini alan tüm Horasanlıların siyah elbise giydiklerine ilişkin haberinden ${ }^{85}$ bu geleneğin İslâm sonrası dönemde de devam ettiği anlaşılmaktadır. Buna rağmen bir rengin belli bir coğrafyanın tüm halkı tarafından çağlar boyunca birtakım olumsuzlukların sembolü yapıldığı gibi genel ifadelerden de kaçınmak gerek. Bizi bu sonuca gö-

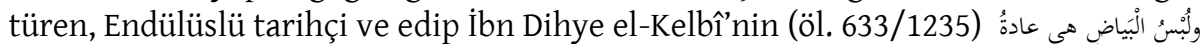

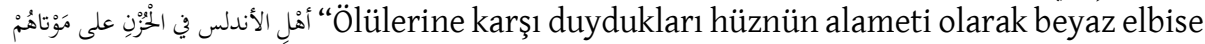
giymek Endülüs halkının âdetidir." ${ }^{" 66}$ şeklindeki açıklamasıdır.

Siyahlığın yan yana getirildiği olumsuz çağrışımların bir diğeri bireylerin toplum içindeki statüsüyle alakalıdır. Biraz daha açacak olursak Arap toplumunda deri rengi siyah olan kişilerin özgürlükten yoksun bireyler olduğu hem doğrudan hem de dolaylı bir şekilde sahip oldukları ten rengine bağlanılmıştır. Bu konuda yazılı kültürün

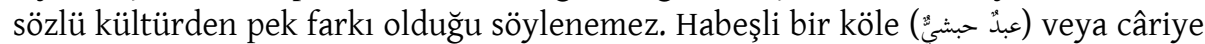
(جاريةٌ حبشيةٌ) ifadesi neredeyse her kaynakta karşımıza çıkmaktadır. Hatta kalem-kılıç, ateş-su, yer-gök gibi iki karşıt unsurun kurgusal münazaralarından biri olan gece-

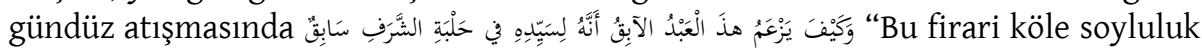
müsabakasında efendisini geçtiğini nasıl iddia edebilir?" cümlesi gece için sarf edilerek sahip olduğu karanlık köle muamelesine maruz kalma nedeni sayılmıştır. ${ }^{87} \mathrm{Bu}-$ nun varyantları Arap toplumunda o kadar yaygınlık kazınmış ki siyahî birini gören bir kişinin onun kim olduğunu sorma gereksinimi duymadan kendisine doğrudan

kara, kara ruhlu, kara cahil, kara bela, karası elinde, yüz karası, kara ağızlı gibi ifadeler sıklıkla kullanılmaktadır. Aynı şekilde kara yer, kara gün, kara kış, kara liste, kara düzen, kara haber, kara yas, kara bela, kara cehennem, kara borsa, kara para, kara bahtlı, kara leke, kara kara düşünmek, , karalama, karaları bağladı, isteyenin bir yüzü vermeyenin iki yüzü kara, ne karanlıkta yat ne kara düş gör, kara gözde olsun yüzde olmasın, ak akçe kara gün içindir, ak gün ağartır, kara gün karartır, el el için ağlamaz; başına kara bağlamaz, ak koyunun kara kuzusu da olur, tencere dibin kara, seninki benden kara, analık fenalık, kara yamalık gibi ölüm, yas, bağnazlık, çirkinlik, kanunsuzluk, şansızlık, cimrilik, korku ve zorluğu tasvir eden atasözü ve deyimlerin tümünde olumsuzluk anlamı ön plandadır.

84 bk. Ebû Akîl Lebîd b. Rebîa b. Mâlik b. Ca'fer el-Âmirî, Dîvânu Lebîd b. Rabi'a Şerhu't'-Ṭ̂sî̀ (Beyrut: Dâru'lKitâbi'l-Arabî, 1414/1993), 47, 60; A'şâ el-Kebîr, Dîvânu el-A'şâ el-Kebîr, 127.

85 Ebû Hanîfe Ahmed b. Dâvûd b. Venend ed-Dîneverî, el-Ahbârü’ț-țvâl, thk. Abdülmün'im Âmir (Kahire: Vizâretü's-Sekâfe ve'l-İrşâdü'l-Kavmî, 1379/1959), 339.

86 Mecdüddîn Ömer b. el-Hasen b. Alî b. Muhammed b. Ferh el-Kelbî, el-Muțrib fí eş'âri ehli'l-Mag̉rib, thk. İbrahim el-Ebyârî vd. (Beyrut: Dâru'l-ìlm li'l-Cemî‘, ts. ), 81.

87 Ahmed b. İbrâhîm b. Mustafâ es-Seyyid el-Hâş̧imî, Cevâhirü'l-edeb fíedebiyyâti ve inşẩi lugiati'l-'Arab (M1sır: el-Mektebetü't-Ticâriyyetü'l-Kübrâ, 1389/1969), 1/268. 
köle muamelesi yaptığı yönünde ilginç rivayetlere bile rastlamak mümkündür. Nitekim İsnâaşeriyye'ye göre on iki imamin sekizincisi Alî er-Rızâ b. Mûsâ el-Kâzım'ı (öl. 203/819) hamamda gören birisi "Ey köle suyu başıma dök!" demesi üzerine, "Ne benim ne de bana 'ey köle' diyenin bir günahı yok. Suç, bana bu karanlığı reva görenindir." ${ }^{88}$ diyen Ali er-Rızâ'nın bu cevabı mevzubahis edilen konunun dikkat çekici bir örneğini teşkil etmektedir.

Klasik Arap edebiyatında hoşlanılmayan kimi durumlar geceye ve onun zifiri karanlığına da benzetilerek aktarılmaya çalışılmıștır. Örneğin saçlarına düşen akları davetsiz misafir olarak nitelendiren Ebü’t-Tayyib el-Mütenebbî (öl. 354/965) إبعدُ بعدة Uzak ol, yok olasin! Senin iyi bir yanın yok, zaten gözümde gece karanlığından daha siyahsın. [Bahr-1 basit] ${ }^{89}$ deyip yavaş yavaş beyazlaşan saçlarına olan kızgınlığını gece karanlığına yüklediği olumsuz bir mana ile ortaya koymuştur. Bu durumda benzer söylemlerde bulunan şairlerin, gecenin gerek korkutucu dinginliği gerekse her türlü kötülüğün işlenmesine müsait bir zaman dilimi oluşunu dikkate aldıkları için olumsuz söylemler geliştirdikleri söylenebilir.

Küşâcim lakaplı Ebü'l-Feth Mahmûd b. el-Hüseyn es-Sindî’nin (öl. 360/971) aşağıda yer verilen beyitlerinde de gecenin rengi üzerinden verilen olumsuz mesajlara temas edilmiştir:

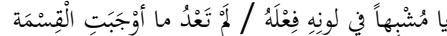

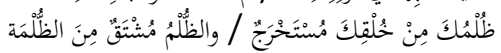

Ey rengi konusunda eylemine benzeyen! Kaderin gerektirdiği şeyden öteye geçmedin. Zorba eylemlerin karakterinden alıntıdır ki (zaten) türevidir zulüm (sözcüğ̈̈) zulmetin. $[\text { Bahr-1 Serî̀ }]^{90}$

Küşâcim, hakaret ettiği kişinin eylemlerini deri rengi üzerinden değerlendirdikten sonra bu durumu onun kaderi saymış, zulüm ve zulmet sözcüklerinin etimolojik bağlantılarını da örnek vererek bir nevi bu hakaretlerinin doğru ve yerinde olduğu izlenimini vermiştir.

Aslında efendi, başkan, lider gibi anlamlara gelen سسِّّ sözcügü ile سواد ve أسود arasındaki kök harflerinin aynı olması siyah rengin karakteristik bir mesaj taşıdığını düşündürse de teorik ve pratikteki örneklerin çoğunda bu minvalde bir anlam kastedil-

88 Ebü's-Safâ Salâhuddîn Halîl b. İzziddîn es-Safedî, el-Vâfi bi'l-vefeyât, thk. Ahmed el-Arnâvût - Türkî Mustafa (Beyrut: Dâru İhyâi't-Türâsi'l-Arabî, 1420/2000), 22/156, 157; Ebû Abdillâh Muhammed b. Ahmed et-Ticânî, Tuhfetü'l-'arûs ve nüzhetü'n-nüfûs, nşr. Celîl el-Atıyye (London: Rıad al-Rayyes Books, 1992), 70. Bu eserin Abdullah b. Muhammed et-Ticânı̂ye ait olduğu ve yanlışlıkla babasına nispet edilerek yayınlandığı belirtilmiştir.

89 Ebü'l-Feth Osmân b. Cinî İbn el-Mevsıllî, el-Fesr Şerḥu dîvâni'l-Mütenebbî, thk. Riza Recep (Dımaşk: Dâru'l-Yenâbic, 2004), 3/448.

90 Küşâcim, Dîvânu Küşâcim, 413. 
memiştir. Dolayısıyla siyah rengi ifade eden sözcüklere etimolojik tahlillerin gerektirdiği anlamlardan çok çevre kültüründen kaynaklı anlamların yüklendiğini söylemek yanlış olmayacaktır.

\section{Sonuç}

Arap dili bazı manaların ifade edilmesi noktasında oldukça zengin bir sözcük dağarcığına sahiptir. Siyah rengin kavram ve anlam boyutu dikkate alındığında bu rengin ifade edilmesi, pekiştirilmesi ve mecazen kullanılmasına ilişkin onlarca sözcük ve ifadeye rastlamak mümkündür. Kendi dönemlerinin en önemli dilcileri tarafından kaleme alınan sözlüklerin yanı sıra gerek İslâm öncesi gerekse İslâm sonrası dönemlerde yaşamış olan şairlerin inşâd ettikleri beyitler siyah renk etrafında şekillenen söz varlığının tespitinde başvurulacak en önemli iki kaynağı oluşturmaktadır.

Arap dilinde siyah, diğer renklere göre hem gerçek hem de sembolik ve mecâzi anlamların daha fazla yüklendiği bir renktir. Ayrıca hem zaman zaman hakarete kaçan olumsuz söylemler hem de karşılıksız aşkın ızdırabıyla dile getirilen özlemler siyah renk aracılığıyla yansıtılmaya çalışılmış ki bu anlamların genelinde Arap Yarımadası'nın yöresel kültürünün izleri net bir şekilde görülmektedir.

Siyah rengin tanımı sayılabilecek açıklamalar ise daha çok bireysel ve sübjektif değerlendirmeler şeklinde olmuştur. Zira kimi âlimlere göre bu renk tıpkı somut bir madde gibi algılanıp görünümünün başka renkler tarafından kapanamaması üzerinden açıklanmış, kimilerine göre kapsam alanı kabul edilmesi mümkün olmayacak düzeyde geniş tutulmuştur. Renkleri ışı̆̆ın cisimler üzerindeki yayılma çeşitliliği ve potansiyelinden oluşan görsel bir duyum şeklinde açılayanlara göre ise siyahlık karanlıkla bir tutulduğu için ne ana ne de ara renk olarak değerlendirilmemiştir.

Siyah rengin en belirgin özelliklerinden biri beyaz renk ile olan kullanımı ve bu iki rengin oluşturduğu kombinasyondur. Göze hoş göründüğü gibi hayatın acı-tatlı olaylarının tasviri noktasında da duygusal bir güzelliği oluşturan siyah-beyaz kombinasyonu genelde saçlardaki siyahlık ve beyazlıkla örneklendirilmiş ve yaşlılık belirtisi olarak algılanan beyaz saçın sebep olduğu fiziksel değişimlerin zamansız olduğuna işaret edilmiştir. Bazen atasözleri, deyimler, beyitler ve olumlu anlamda düşünmeye yönlendiren hikmetli cümlelerde de karşımıza çıkan bu kombinasyona o kadar ilgi çekici anlamlar yüklenmiş ki birbirinin karşıtı olan bu renklerin biri adeta diğerinin mütemmimi mesabesinde görülmüştür. 


\section{Kaynakça}

Antere b. Şeddâd. Dîvânu 'Antere. thk. Muhammed Saîd Mevlevî. Kahire: el-Mektebetü'l-İslâmî, 1390/1970.

A'şâ el-Kebîr, Ebû Basîr Meymûn b. Kays b. Cendel el-Bekrî. Dîvânu el-A'şâ el-Kebîr. thk. Muhammed Hüseyin. b.y.: Mektebetü'l-Âdâb el-Matbaatu'n-Numûzeciyye, 1950.

A'şâ Hemdân, Ebü'l-Musabbih Abdurrahmân b. Hâris. Dîvânu A'şâ Hemdân ve ahbâruh. thk. Hasan Îsâ Ebû Yâsîn. Riyad: Dâru'l-Ulûm, 1403/1983.

Ahtal, Ebû Mâlik Giyâs b. Gavs b. es-Salt. Dîvânu el-Ahțal. haz. Mehdî Muhammed Nâs1ruddîn. Beyrut: Dâru'l-Kütübi'l-i̇lmiyye, 2. Basım, 1414/1994.

Asmaî, Ebû Saîd Abdülmelik b. Kureyb el-Bâhilî. el-Așmaciyyât. thk. Ahmed Muhammed Şâkir - Abdüsselâm Hârûn. Beyrut: y.y. 5. Basım, 1375/1955.

Aceyne, Muhammed. Mevsû'atu esâțîri'l-‘Arab 'ani'l-câhiliyyye ve delâletihâ. 2 Cilt. Beyrut: Dâru'l-Fârâbî, 1994.

Ahmed el-Hâşimî. Cevâhirü'l-edeb fî edebiyyâti ve inşẩi luġati'l-‘Arab. Mısır: el-Mektebetü't-Ticâriyyetü'l-Kübrâ, 1389/1969.

Bağcı, Serpil. "İslam Toplumlarında Matemi Simgeleyen Renkler: Mavi, Mor ve Siyah”. Ankara Türk Tarih Kurumu Yayınları, 2, (1996), 163-168.

Bişr b. Ebî Hâzim, Ebû Nevfel el-Esedî. Dîvânu Bişr b. Ebî Hâazim el-Esedî. nşr. Mecîd Tarrâd. Beyrut: Dâru'l-Kitâbi'l-Arabî, 1415/1994.

Butrus b. Bûlus el-Bustânî. Muhîțï'l-Muhîț. Beyrut: Dâiretü'l-Maâcim Mektebetu Lübnan, 1987.

Büyükcoşkun, Kudret. “Arabistan”. Türkiye Diyanet Vakfi İslâm Ansiklopedisi. Erişim 16 Temmuz 2021. https://islamansiklopedisi.org.tr/arabistan

Câhiz, Ebû Osmân Amr b. Bahr b. Mahbûb. Rasẩilü'l-Câhiz. thk. Abdüsselâm Muhammed Hârûn. 4 Cilt. Kahire: Mektebetü'l-Hânecî, 1384/1964.

Câhiz, Ebû Osmân Amr b. Bahr b. Mahbûb. Kitâbü'l-Hayevân. thk. Abdüsselâm Muhammed Hârûn. 8 Cilt. Kahire: Matbaatu Mustafa el-Bâbi'l-Halebî, 1385/1965.

Cemîl Buseyne, Ebû Amr Cemîl b. Abdillâh b. Ma'mer el-Uzrî. Dîvânu Cemîl Buseyne. nşr. Butrus el-Bustânî. Beyrut: Dâru Beyrut, 1402/1982.

Cerîr b. Atıyye. Dîvânu Cerîr bi şerḥi Muhammed b. Habîb. thk. Numan Muhammed Emin Taha. 2 Cilt. Kahire: Dâru'l-Maârif, 2. Basım, ts.

Cevherî, Ebû Nasr İsmâil b. Hammâd. eș-Ṣıhâh tâcü'l-lüga ve Șihâhiü'l-‘Arabiyye. thk. Ahmed Abdülgafûr Attâr. 6 Cilt. Beyrut: Dâru'l-i̇lm li'l-Melâyîn, 2. Basım, 1399/1979.

Cirân el-Avn en-Numeyrî, Âmir el-Hâris b. Kelefe. Dîvânu Cirâni'l-avd en-Numeyrî. thk. Karîn Sâdır. Beyrut: Dâru Sâdır, 1999. 
Düreyd b. es-Simme, Ebû Amr. Dîvânu Düreyd b. eș-Ṣımme. thk. Ömer Abdürresül. Beyrut: Dâru'l-Maârif, ts.

Entâkî, Davûd b. Ömer. Tezyînü'l-esvâk bi tafșilli eşvâki'l-'uşşâk. thk. Emîn Abdülcâbir elBuhayrî. 2 Cilt. Kahire: Dâru'l-Beyâni'l-Arabî, ts.

Emel Mahmûd Abdülkādir Ebû Avn. el-Levn ve eb âduh fi'ş-şiri'i'-Câhili Şu'arâ'ü'l-mu'allakāt enmûzecen. Nablus: Câmi âtü'n-Necâh el-Vataniyye, Yüksek Lisans Tezi, 2003.

Ezherî, Ebû Mansûr Muhammed b. Ahmed. Tehzîüül-luġa. thk. Abdüsselâm Muhammed Hârûn vd. 16 Cilt. Mısır: ed-Dâru'l-Mısriyye li't-Telîf ve't-Terceme, ts.

Ebû Amr eş-Şeybânî, İshâk b. Mirâr, Kitâbü'l-Cîm. thk. İbrahim el-Ebyârî - Abdülalîm et-Tahâvî, 3 Cilt. Kahire: el-Hey'etü'l-âmme li Şuûni'l-Metâbi'i'l-Emîriyye, 1294/1974.

Ebû Alî el-Kālî, İsmâîl b. el-Kāsım b. Ayzûn. Kitâbü'l-Emâlî ve'z-žeylu ve't-tenbîh. 4 Cilt. Misır: el-Hey'etü'l-Misriyyetü'l-Âmme li'l-Kitâb, 1975.

Ebû Züeyb el-Hüzelî, Huveylid b. Hâlid b. Muharris. Dîvânu Ebî Zü̉eyb el-Hüželī. thk. Ahmed Halîl eş-şâl. Port Said: Merkezu'd-Dirâsât ve'l-Buhûsi'l-İslâmiyye, $1435 / 2014$.

Ebû Zeyd el-Ensârî, Saîd b. Evs b. Sâbit. Kitâbü'n-Nevâdir fi'l-luġa. thk. Muhammed Abdülkādir Ahmed. Beyrut: Dâru'ş-Şurûk, 1401/1981.

Ebü'l-Atâhiye, Ebû İshâk İsmâîl b. el-Kāsım b. Süveyd. Dîvânu Ebi'l-'Atâhiye. Beyrut: Dâru Beyrut, 1406/1986.

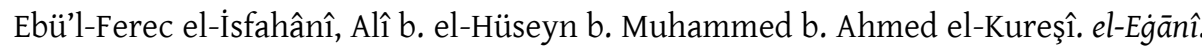
25 Cilt. Beyrut: Dâru İhyâi't-Türâsi'l-Arabî, 1415/1994.

Ebü'l-Hasan et-Tehâmî, Ali b. Muhammed. Dîvânu Ebi'l-Hasan Ali b. Muhammed etTehâmî. thk. Muhammed Abdurrahman er-Rabî‘. Riyad: Mektebetü'l-Maârif, 1402/1982.

Ebû Hanîfe ed-Dîneverî, Ahmed b. Dâvûd b. Venend. el-Ahbârü'ț-țvâl. thk. Abdülmün'im Âmir. Kahire: Vizâretü's-Sekâfe ve'l-İ̀şâdü'l-Kavmî, 1379/1959.

Erten, Nesrin Bayraktar. "Kara ve Siyah Renk Adlarının Türkçedeki Kavram ve Anlam Boyutu Üzerine”. Dil Dergisi, 126 (2004), 56-77.

Ferezdak, Ebû Firâs Hemmâm b. Gālib b. Sa'saa. Dîvânu'l- Ferezdak. thk. Ali Fâ'ûr. Beyrut: Dâru'l-Kütübi'l-'İlmiyye, 1407/1987.

Feyyûmî, Ebü'l-Abbâs Ahmed b. Muhammed b. Alî. el-Mișbâhu'l-münîr fi ġarîbi'ş-şerhi'lkebîr li'r-Râficî. thk. Abdülazîm eş-Şinnâvî. Kahire: Dâru'l-Maârif, 2. Basım, 1397/1977. 
Fîrûzâbâdî, Mecdüddîn Muhammed b. Ya'kūb b. Muhammed. el-Kāamûsü'l-muhîț. thk. Komisyon. Beyrut: Müessesetü'r-Risâle, 8. Basım, 1426/2005.

Gündüzöz, Soner. “Kur’ân'da Renklerin Büyülü Gücü Semiotik Bir İnceleme”. EKEV Akademi Dergisi. 16, (Yaz 2003), 71-84.

Gündüzöz, Soner. “Arap Sözlük Bilimi ve Sözlük Çalışmaları”. İslam Medeniyetinde Dil İlimleri Tarih ve Problemler, 23-77. ed. İsmail Güler. İstanbul: İSAM Yayınları, 2015.

Güfta, Hüseyin. “Bâkî Divanı'nda Siyah Renkli Unsurlar”. Turkish Studies, International Periodical For the Languages, Literature and History of Turkish or Turkic. 4/8, (2009), 1314-1373.

Halil b. Ahmed, Ebû Abdirrahmân. Kitâbü'l-‘Ayn müratteben alâ hurûfi'l-mu'cem. thk. Abdulhamîd Hindâvî. 4 Cilt. Beyrut: Dâru'l-Kütübi'l-i̇lmiyye, 1424/2003.

Hâris b. Hillize, Ebû Ubeyde. Dîvânu el-Hâris b. Hillize. haz. Emîl Bedî‘ Ya'kūb. Beyrut: Dâru'l-Kitâbi'l-Arabî, 1411/1991.

Hatîb et-Tebrîzî, Ebû Zekeriyyâ Yahyâ b. Alî b. Muhammed. Şerḥu Dîvâni 'Antere. haz. Mecîd Tarrâd. Beyrut: Dâru'l-Kitâbi'l-Arabî, 1412/1992.

Hatîb et-Tebrîzî, Ebû Zekeriyyâ Yahyâ b. Alî b. Muhammed. Şerhu Dîvâni Ebî Temmâm. thk. Râcî el-Esmer. 2 Cilt. Beyrut: Dâru'l-Kitabi'l-Arabî, 2. Basım, 1414/1994.

Hufâf b. Nüdbe es-Sülemî. Şi'ru Hufāf b. Nudbe es-Sülemî. thk. Nuri Hammûdî el-Kaysî. Bağdad: Matbaatu'l-Maârif, 1968.

Îcî, Ebü'l-Fazl Adudüddîn Abdurrahmân b. Ahmed b. Abdilgaffâr. el-Mevâkııffí cilmi'lkelâm. Beyrut: Âlemü'l-Kütüb, 2005.

İmruülkays, Ebû Vehb Hunduc b. Hucr b. el-Hâris. Dîvânu İmri'i'l-Kays ve mulhakātuh bi şerhi Ebî Saî̀ es-Sükkerî. thk. Enver Alyan Ebû Süveylim - Muhammed eşŞevâbike. 2 Cilt. Birleşik Arap Emirlikleri: Merkezu Zâyid li’t-Türâs ve’t-Târih, $1421 / 2000$.

İliyyâ el-Hâvî. Şerḥu Dîvâni'l-Ferezdak. 2 Cilt. Beyrut: Dâru'l-Kütübi'l-Lübnânî Mektebetü'l-Medrese, 1983.

İbnü'l-Cevzî, Ebü'l-Ferec Cemâlüddîn Abdurrahmân b. Alî. Garîbü'l-hadîs. nşr. Abdülmưtî Emîn Kal'acî. 2 Cilt. Beyrut: Dâru'l-Kütübi'l-İlmiyye, 1425/2004.

İbnü’s-Sikkît, Ebû Yûsuf Ya'kūb b. İshâk. Kitâbü'l-Elfâz. thk. Fahreddîn Kabâve. Beyrut: Mektebetu Lübnan, 1998.

İbnü'l-Enbârî, Ebû Bekr Muhammed b. el-Kāsım b. Muhammed. Şerḥu'l-Kașẩidi'sseb'i'ț-țvâli'l-Câhiliyyât. thk. Abdüsselâm Muhammed Hârûn. Kahire: Dâru'lMaârif, 5. Basım, ts. 
İbnü'l-Enbârî, Ebû Bekr Muhammed b. el-Kāsım b. Muhammed. ez-Zâhir fì me'ânî kelimâti'n-nâs. thk. Hâtim Sâlih ed-Dâmin. 2 Cilt. Beyrut: Müessesetü'r-Risâle, 1412/1992.

İbn Asâkir, Ebü'l-Kāsım Alî b. el-Hasen b. Hibetillâh b. Abdillâh. Târîhu medîneti Dtmaş.. thk. Ebû Saîd Ömer b. Garâme el-Amrevî. 80 Cilt. Beyrut: Dâru'l-Fikr, 1415/1995.

İbn Abdürabbih, Ebû Ömer Şihâbüddîn Ahmed b. Muhammed. el-'ikkdü'l-ferîd. thk. Müfîd Muhammed Kamiha - Abdülmecîd et-Terhînî. 9 Cilt. Beyrut: Dâru'l-Kütübi'l-i̇lmiyye, 1404/1983.

İbn Cinnî, Ebü'l-Feth Osmân. el-Fesr Şerhu İbn Cinnî el-kebîr 'alâ dîvâni'l-Mütenebbî. thk. Riza Recep. 4 Cilt. Dımaşk: Dâru'l-Yenâbî', 2004.

İbn Dihye el-Kelbî, Mecdüddîn Ömer b. el-Hasen b. Alî. el-Muțrib fí eş̧âri ehli'l-Maǵrib. thk. İbrahim el-Ebyârî vd. Beyrut: Dâru'l-İlm li'l-Cemî`, ts.

İbn Ebû Avn, Ebû İshâk İbrâhîm b. Muhammed b. Ahmed. Kitâbü't-Teşbîhât. nşr. Muhammed Abdülmuîd Hân. London: Câmiatu Cambridge, 1369/ 1950.

İbn Fâris, Ebü'l-Hüseyn Ahmed b. Fâris b. Zekeriyyâ. Mu'cemü mekāyîsi'l-luġa. thk. Abdüsselâm Muhammed Hârûn. 6 Cilt. Kahire: Dâru'l-Fikr, 1372/1972.

İbn Hazm, Ebû Muhammed Alîb. Ahmed b. Saîd b. Hazm. el-Faṣl fill-milel ve'l-ehvâ’ ve'nnihal. 5 Cilt. b.y. Mektebetü's-Selâmi'l-Alemiyye, ts.

İbn Hüzeyl el-Endelüsî, Ebü'l-Hasen Alî b. Abdirrahmân. Hilyetü'l-fürsân ve şu'arâ’u'şşec'ân. nşr. Muhammed Abdülganî Hasan. Kahire: Dâru'l-Maârif, 1369/1949.

İbn Sîde, Ebü'l-Hasen Alî b. İsmâîl b. Sîde. el-Muhkem ve'l-muhîtü'l-a'zam, thk. Mustafa es-Sekkā vd. 7 Cilt. Kahire: Ma'hedü'l-Mahtûtât bi Câmiati'l-Lügati'l-Arabiyye, 1393/1973.

İbn Sîde, Ebü'l-Hasen Alî b. İsmâîl b. Sîde. el-Muhașsạaṣ. 17 Cilt. Beyrut: Dâru'l-Kütübi'lİlmiyye, ts.

İbn Mâce, Ebû Abdillâh Muhammed b. Yezîd Mâce el-Kazvînî. Sünenü İbn Mâce. nşr. Muhammed Nâsırüddîn el-Albânî. Riyad: Mektebetü'l-Maârif, ts.

İbn Manzûr, Ebü'l-Fazl Cemâlüddîn Muhammed b. Mükerrem. Lisânü'l-'Arab. thk. Komisyon. 15 Cilt. Beyrut: Dâru Sâdır, ts.

İbn Manzûr, Ebü'l-Fazl Cemâlüddîn Muhammed b. Mükerrem. Nišârü'l-ezhâr fi'l-leyli ve'n-nehâr. Kostantiniyye: Matbaatu'l-Cevânib, 1298.

İbn Meymûn, Ebû Gālib Muhammed b. el-Mübârek b. Muhammed. Müntehe't-țaleb min eş'âri'l-'Arab. thk. Muhammed Nebîl Turayfî. 10 Cilt. Beyrut: Dâru Sâdır, 1999.

İbn Mukbil, Ebû Kấb Temîm b. Übey b. Mukbil b. Avf el-Aclânî. Dîvânu İbn Mukbil. thk. İzzet Hasan. Beyrut: Dâru'ş-Şarki'l-Arabî, 1416/1995. 
İbn Düreyd el-Ezdî, Ebû Bekr Muhammed b. el-Hasen. Cemheretül-lüga. thk. Remzî Münîr Ba'lbekî. 3 Cilt. Beyrut: Dâru'l-i̇lm li'l-Melâyîn, 1987.

İbn Düreyd el-Ezdî, Ebû Bekr Muhammed b. el-Hasen. Makșûretu İbn Düreyd. haz. İyd el-Vasif Muhammed. Dubai: Matbaatu Golden City, 2012.

İbn Dürüsteveyh, Ebû Muhammed Abdullah b. Ca'fer. Tașhîhu'l-Fașîh. thk. Muhammed Bedevî el-Mahtûn - Ramazan Abdüttevvâb. Kahire: Metâbiu't-Ticâriyye, $1425 / 2004$.

Kalkaşendî, Ebü'l-Abbâs Şihâbüddîn Ahmed b. Alî. Șubhu'l-a'şâ fî șınâ'ati'l-inşâ. 14 Cilt. Kahire: Dâru'l-Kütübi'l-Misriyye, 1340/1922.

Küşâcim, Ebü'l-Feth Mahmûd b. el-Hüseyn. Dîvânu Küşâcim. thk. Nebevî Abdülvâhid Şa'lân. Kahire: Mektebetü'l-Hâncî, 1417/1997.

Kudâme b. Ca'fer, Ebü'l-Ferec el-Bağdâdî. Cevâhirü'l-elfâz. thk. Muhammed Muhyiddin Abdülhamîd. Kahire: y.y. 1350/1932.

Kutâmî, Umeyr b. Şüyeym b. Amr. Dîvânu'l-Kuțâmî. thk. İbrahim es-Sâmirâî - Ahmed Matlub. Beyrut: Dâru's-Sekâfe, 1960.

Kuranmeali.com. Erişim 6 Nisan 2021. AyetKarsilastirma.php?sure $=24 \&$ ayet $=40$

Lebîd b. Rebîa el-Âmirî, Ebû Akîl. Dîvânu Lebîd b. Rabi'a Şerhu'ț-Ṭ̂îî. Beyrut: Dâru'lKitâbi'l-Arabî, 1414/1993.

Merzûkī, Ebû Alî Ahmed b. Muhammed b. el-Hasen. Şerhu Dîvâni'l-Hamâse. haz. Ğarîd eş-Şeyh - İbrahim Şemsüddîn. 4 Cilt. Beyrut: Dâru'l-Kütübi'l-İlmiyye, 1434/2003.

Meydânî, Ebü'l-Fazl Ahmed b. Muhammed b. Ahmed b. İbrâhîm. Mecma'u'l-emsâal, thk. Muhammed Muhyiddin Abdülhamîd. 2 Cilt. Kahire: Matbaatu's-Sünneti'l-Muhammediyye, 1374/1955.

Mutarrizî, Ebü'l-Feth Burhânüddîn Nâsır b. Abdisseyyid. el-Mugirib fî tertîbi'l-Mu'rib. thk. Mahmûd Fâhûrî - Abdülhamîd Muhtâr. 2 Cilt. Haleb: Mektebetu Üsâme b. Zeyd, 1399/1979.

Mufaddal ed-Dabbî, Ebü'l-Abbâs Mufaddal b. Muhammed. el-Fâhir fi'l-emsâ̂l. haz. Muhammed Osman. Beyrut: Dâru'l-Kütübi'l-i̇lmiyye, 2011.

Nâbiga ez-Zübyânî, Ebû Ümâme Ziyâd b. Muâviye. Dîvânu en-Nâbiġa ez-Zübyânî, haz. Muhammed et-Tâhir İbn Âşûr. Cezayir: eş-Şerîketü'l-Vataniyye li'n-Neşr ve'tTevzî‘, 1976.

Nâbiga el-Cacdî, Ebû Leylâ Kays b. Abdillâh b. Rebîa. Dîvânu en-Nâbiga el-Cacdî. thk. Vâdih es-Samed. Beyrut: Dâru Sâdır, 1998.

Nasîrüddîn et-Tûsî, Ebû Cacfer Muhammed b. Muhammed b. el-Hasen. TelhîṣülMuhașșal el-ma'rûf bi Nakdi'l-Muhașșal. Beyrut: Dâru'l-Edvâ', 1405/1985. 
Nehhâs, Ebû Ca'fer Ahmed b. Muhammed b. İsmâîl. Şerhu'l-kașâ'idi't-tis'i’l-meşhûrâti'lmevsûmeti bi'l-Mu'allakāt. thk. Ahmed Hattâb. 2 Cilt. Bağdat: Dâru'l-Hurriye li'tTabbâ'a, 1393/1973.

Nemerî, Ebû Abdillâh el-Hüseyn b. Ali. Kitâbü'l-Mülemmac' thk. Vecihe Ahmed es-Sezal. Dımaşk: Matbaatu Zeyd b. Sâbit, 1396/1976.

Nüveyrî, Ebü'l-Abbâs Şihâbüddîn Ahmed b. Abdilvehhâb b. Muhammed. Nihâyetü'lereb fî fünûni'l-edeb. thk. Müfîd Kamîha. 33 Cilt. Beyrut: Dâru'l-Kütübi'l-İlmiyye, $1424 / 2004$.

Özcan, Behiye Asude. "Türk ve Slav Kültüründe Siyah Renk”, Akademik Tarih ve Düşünce Dergisi. 5/18 (2018), 269-292.

Parlak, Sevda Demir. Kadın Giyim Modasında Siyah Renk. İzmir: Dokuz Eylül Üniversitesi Güzel Sanatlar Enstitüsü, Yüksek Lisans Tezi, 2020.

Radî el-Esterâbâdî, Necmü'l-eimme Radıyyüddîn Muhammed b. el-Hasen. Şerḥu'şŞâfiye. thk. Muhammed Muhyiddin Abdülhamîd vd. 3 Cilt. Beyrut: Dâru'l-Kütübi'lİlmiyye, 1402/1982.

Radî el-Esterâbâdî, Necmü'l-eimme Radıyyüddîn Muhammed b. el-Hasen. Şerhu'rRaḍ̂ 'ale'l-Kâfiye. nşr. Yûsuf Hasan Ömer. 4 Cilt. Bingazi: Menşûrâtu Câmiati Karyûnus, 2. Basım, 1996.

Safedî, Ebü's-Safâ Salâhuddîn Halîl b. İzziddîn. el-Vâfî bi'l-vefeyât. thk. Ahmed elArnâvût - Türkî Mustafa. 29 Cilt. Beyrut: Dâru İhyâi't-Türâsi'l-Arabî, 1420/2000.

Sâbit b. Ebû Sâbit. Ebû Muhammed Saîd el-Kûfî el-Lugavî. Halkủl-insân. thk. Abdüssettâr Ahmed Ferrâc. Kuveyt: Matbaatu Hukûmeti Kuveyt, 2. Basım, 1985.

Seyyid Şerîf el-Cürcânî, Ebü'l-Hasen Alî b. Muhammed b. Alî. et-Ta'rîfât. haz. Muhammed Bâsil Uyûn es-Sûd. Beyrut: Dâru'l-Kütübi'l-i̇lmiyye, 1424/2003.

Seâlibî, Ebû Mansûr Abdülmelik b. Muhammed b. İsmâ̂ll. Yetîmetü'd-dehr fî mehâasini ehli'l-'așr. nşr. Müfîd Muhammed Kumeyha. 5 Cilt. Beyrut: Dâru'l-Kütübi'l-ìlmiyye, 1403/1983.

Seâlibî, Ebû Mansûr Abdülmelik b. Muhammed b. İsmâîl. Fikhü'l-luġa ve strrü'l-‘Arabiyye. haz. Yasin el-Eyyûbî. Beyrut: el-Mektebetü'l-Asriyye Seydâ, 2. Basim, $1420 / 2000$.

Sa'leb, Ebü'l-Abbâs Ahmed b. Yahyâ b. Zeyd eş-Şeybânî. Kitâbü'l-Fașîh. nşr. Von Barth. Leipzig: y.y. 1876.

Sîbeveyhi, Ebû Bişr Amr b. Osmân b. Kanber. el-Kitâb. thk. Abdüsselâm Muhammed Hârûn. 5 Cilt. Kahire: Mektebetü'l-Hâncî, 3. Basım, 1408/1988.

Sükkerî, Ebû Saîd el-Hasen b. el-Hüseyn b. Ubeydillâh. Dîvânu'l-Hüzeliyyîn. 3 Cilt. Kahire: Matbaatu Dâri'l-Kütübi'l-Mısriyye, 2. Basım, 1995. 
Sükkerî, Ebû Saîd el-Hasen b. el-Hüseyn b. Ubeydillâh. Şi'ru'l-Ahțal Ebî Mâlik Ġyâs b. Ǵavs et-taġlebî. thk. Fahreddin Kabâve. Dımaşk: Dâru'l-Fikr, 1414/1996.

Sükkerî, Ebû Saîd el-Hasen b. el-Hüseyn b. Ubeydillâh. Dîvânu Ebi'l-Esved ed-Düelî. thk. Muhammed Hasan Âl Yâsîn. Beyrut: Dâru Mektebeti'l-Hilâl, 1418/1998.

Şemmâh b. Dirâr. Dîvânu eş-Şemmâh b. Żirâr ez- Zübyânî. thk. Selâhüddîn el-Hâdî. Kahire: Dâru'l-Maârif bi Misır, 1968.

Şihâbüddîn el-Hafâcî, Ahmed b. Muhammed b. Ömer. Şerḥu Dürreti'l-ġavvâș fi evhâmi'lhavâṣ. thk. Meysûn Abdüsselam Necib. Abu Dabi: Dâru'l-Kütübi'l-Vataniyye, $1433 / 2012$.

Tarafe (Amr) b. el-Abd el-Vâilî, Ebû Amr. Dîvânu Tarafe b. el-Abd. haz. Mehdî Muhammed Nasırüddin. Beyrut: Dâru'l-Kütübi'l-İlmiyye, 3. Basım, 1423/2002.

Teftâzânî, Sa'düddîn Mes'ûd b. Fahrüddîn. Şerḥu'l-Makāṣıd, thk. Abdurrahman Umeyre. 5 Cilt. Beyrut: Âlemü'l-Kütüb, 3. Basım, 1419/1998.

Tehânevî, Muhammed A'lâ b. Alî b. Muhammed Hâmid. Keşşâfü ıșțlâhhâti’l-fünûn ve’l'ulûm. thk. Ali Dahrûc. 2 Cilt. Beyrut: Mektebetu Lübnan, 1996.

Topaloğlu, Aydın. "Renk", Türkiye Diyanet Vakfi İslâm Ansiklopedisi. Erişim 24 Kasım 2020. https://islamansiklopedisi.org.tr/renk\#2-felsefe

Tenûhî, Ebû Alî el-Muhassin b. Alî b. Muhammed el-Kādî. Nişvârü'l-muhâdara ve ahbârü'l-müzâkere. nşr. Abbûd eş-Şâlcî. 8 Cilt. Beyrut: Dâru Sâdır, 2. Basım, 1995.

Ticânî, Ebû Abdillâh Muhammed b. Ahmed. Tuhfetü'l-'arûs ve nüzhetü'n-nüfûs, nşr. Celîl el-Atıyye. London: Riad al-Rayyes Books, 1992.

Ubeyd b el-Ebras el-Esedî. Dîvânu 'Ubeyd b. el-Ebraș. thk. Eşref Ahmed Adare. Beyrut: Dâru'l-Kitâbi'l-Arabî, 1414/1994.

Ukaylî, Beşşâr b. Bürd. Dîvânu şi'ri Beşşâr b. Bürd. thk. es-Seyyid Bedrüddîn el-Alevî. Beyrut: Dâru's-Sekâfe, 1981.

Ukaylî, Beşşâr b. Bürd. Dîvânu Beşşâr b. Bürd. nşr. Muhammed et-Tâhir b. Âşûr. 2 Cilt. Cezair: Vizâretü'l-Evkâf, 2007.

Yâkût el-Hamevî, Ebû Abdillâh Şihâbüddîn Yâkūt b. Abdillâh. Mu'cemü'l-büldân. thk. Ferîd Abdülazîz el-Cündî. 7 Cilt. Beyrut: Dâru'l-Kütübi'l-İlmiyye, 1410/1990.

Zehebî, Ebû Abdillâh Muhammed b. Ahmed b. Osmân. Siyeru a'lâmi'n-nübelâ’. thk. Şuayb el-Arnâvût. 25 Cilt. Beyrut: Müessesetü'r-Risâle, 2. Basım, 1402/1982.

Zebîdî, Ebü'l-Feyz Muhammed el-Murtazâ b. Muhammed el-Hüseynî. Tâcü'l-‘arûs min cevâhiri'l-Kāmûs. thk. Hüseyin Nessâr. 40 Cilt. Kuveyt: Matbaatu Hukûmeti'l-Kuveyt, 1969. 
Zemahşerî, Ebü'l-Kāsım Mahmûd b. Ömer. el-Fẩik fî̀ arîbi'l-hadîs. thk. Ali Muhammed el-Bicâvî - Muhammed Ebü'l-Fazl İbrâhim. 4 Cilt. Kahire: Matbaatu Îsâ el-Bâbi'lHalebî ve Şurekâuh, 2. Basım, ts.

Zemahşerî, Ebü'l-Kāsım Mahmûd b. Ömer. Esâsü'l-belaġa. thk. Muhammed Bâsil Uyûn e's-Sûd. 2 Cilt. Beyrut: Dâru'l-Kütübi'l-İlmiyye, 1419/1998.

Zübeydî, Ebû Bekr Muhammed b. el-Hasen b. Abdillâh. Lahnü̈l-`avâm. thk. Ramazan Abdüttevvâb. Kahire: Mektebetü'l-Hâncî, 2. Basım, 1420/2000.

Zevzenî, Ebû Abdillâh Hüseyn b. Ahmed. Şerḥu'l-Mu'allakāti's-sebc. thk. Komisyon. Beyrut: ed-Dâru'l-Âlemiyye, 1413/ 1992.

Zürrumme, Ebü'l-Hâris Gaylân b. Ukbe b. Ma'dî b. Amr. Dîvânu Zürrumme. haz. Ahmed Hasan Besec. Beyrut: Dâru'l-Kütübi'l-İlmiyye, 1415/1995. 


\section{Colour Black in Arabic from in Perspective of Concept and Meaning Dimension}

\section{Extended Abstract}

The concepts formed in the thought of human are his actions to produce meaning and this action is formed by the language depending on his development level. However, each concept becomes functional with the fact that it is open meaning changes through the historical process and with meaning layers occurring at this time. So, the concept and meaning dimension of a being can merely be established with the richness of the words reflected to the language and expressions. Without doubt, the existence of some meanings and differences and diversities in Arabic will not only make the framework of both dimensions but also it will facilitate to obtain some information within this context. Because Arabic with an ancient past has many distinctive features such as both rich vocabulary source and numerous metaphorical use, especially with the phenomenon of masculinity and femininity and potential to possess secondary and connotation meanings, and its ability to literary arts and the broadness of its derivativeness. In fact, it is possible to determine these distinctive features of Arabic by looking into the existence of word formed around many meanings, which is clearly seen in the case of words and expressions used in conceptual and meaning dimension of colour black. Besides the dictionaries written by prominent linguists of the time, the poetic lines uttered by poets of both pre and post-Islamic periods make the two important sources to be applied in determining the vocabulary source formed the colour in question. Because while the analysis of any concept is made, it sets significance to examine the poetry magazines as the divans and anthologies of classical period poets accepted as one of the primitive lexicon work in terms of pursuing the conceptual diversity traces. In this context, as well as the meanings attributed to the colour black, the words used to express this colour, the stereotypes used to make it clear and reinforce it on the basis of the entity with which it is identified, its use in some sentence phrases and idioms with different colours, its expression with words used for black people, the existence of a rich vocabulary are witnessed in making the metaphorical language of platonic love, individual desires and longings in the form of sawād al-kalb (the black of heart ) القَّبَ) (سَوادُ in general. On the other hand, trying to describe it with the words akhdar (أَخْضرَ) and khudrr (خُضْر) meaning skin colour and pitch dark green in classical Arabic poetry shows that these words mean blackness and darkness. Considering the negative connotations of the colour black and the positive connotations of green, the fact that the skin colour is called "akhdar" (green) in the Arab society indirectly brings to mind the discomfort felt when the dark skin colour is described as aswad (black) (أسود).

In the Arabic, black is a colour that has both literal and symbolic and figurative meanings, and it is mostly used with white. This is the most important feature that 
distinguishes it from other colours. The combination of black and white, which creates a spiritual beauty in the depiction of the bitter-sweet events of life, as well as pleasing to the eye, is often seen over the black and whiteness of the hair, as well as in proverbs, idioms and sentences that lead to positive thinking. In fact, if the messages intended to be given through words of wisdom, poetry, idioms and proverbs are examined, it can be said that these colours, which are opposite to each other, are used as a complement to the other. The opinions put forward about the explanations that can be considered as the definition of this colour are at least as remarkable as the vocabulary formed around this colour. Because, according to some scholars, this colour is perceived as a concrete substance and explained by the fact that it cannot be covered by other colours, and according to some, its scope is almost ignored. According to some, it is defined as "the perception of the light emitted by the objects with the eyes or a visual sensation consisting of the spread, variety and potential of the light on the objects" and counted as neither primary nor secondary colours.

When we look at the pre and post-Islamic literature, it will be seen that the colour black, which is the opposite of white, which is perceived as a symbol of beauty and attractiveness, is approached beautifully and positively only when it comes to the lover's hair, eyes and moles on his body. These colour othering discourses, are used more in situations such as, acts of humiliation and contempt, signs of destruction and devastation, symbolizing pain, grief and creepiness. In addition, both the negative discourses that are sometimes insulting and the longings expressed with the suffering of unrequited love are tried to be reflected through the meanings attributed to the colour black; and it is clearly seen that in general sense of these meanings, the traces of the local culture of the Arabian Peninsula, the prejudices that a person acquires later and the traditions that become taboo are evident. Sometimes, some disliked situations are tried to be conveyed by poets and literary men as similarizing them to the night and its pitch darkness. In this case, it can be said that the poets, who have similar discourses, have developed negative discourses because they have taken the frightening calmness of the night into account and the fact that it is a period suitable for all kinds of evils to be committed.

Although the root letters of the word w ساد - سود and meaning such as master, president, leader, chief, gentleman, and أسود and ang ang ang the same, and suggest that the colour black carries a characteristic message, it is seen that most of the theoretical and practical examples do not have a positive meaning.

Keywords: Arabic Language, Arab Literature, Concept, Meaning, Black, Colour. 